\title{
Metabolic activities and molecular investigations of the ameliorative impact of some growth biostimulators on chilling- stressed coriander (Coriandrum sativum L.) plant
}

Raifa A. Hassanein ${ }^{1}$, Omaima S. Hussein², Amal F. Abdelkader', Iman A. Farag², Yousra E. Hassan² and Mohamed Ibrahim ${ }^{1 *}$ (I)

\begin{abstract}
Background: Priming of seed prior chilling is regarded as one of the methods to promote seeds germination, whole plant growth, and yield components. The application of biostimulants was reported as beneficial for protecting many plants from biotic or abiotic stresses. Their value was as important to be involved in improving the growth parameters of plants. Also, they were practiced in the regulation of various metabolic pathways to enhance acclimation and tolerance in coriander against chilling stress. To our knowledge, little is deciphered about the molecular mechanisms underpinning the ameliorative impact of biostimulants in the context of understanding the link and overlap between improved morphological characters, induced metabolic processes, and upregulated gene expression. In this study, the ameliorative effect(s) of potassium silicate, HA, and gamma radiation on acclimation of coriander to tolerate chilling stress was evaluated by integrating the data of growth, yield, physiological and molecular aspects.

Results: Plant growth, yield components, and metabolic activities were generally diminished in chilling-stressed coriander plants. On the other hand, levels of ABA and soluble sugars were increased. Alleviation treatment by humic acid, followed by silicate and gamma irradiation, has notably promoted plant growth parameters and yield components in chilling-stressed coriander plants. This improvement was concomitant with a significant increase in phytohormones, photosynthetic pigments, carbohydrate contents, antioxidants defense system, and induction of large subunit of RuBisCO enzyme production. The assembly of Toc complex subunits was maintained, and even their expression was stimulated (especially Toc75 and Toc 34) upon alleviation of the chilling stress by applied biostimulators. Collectively, humic acid was the best the element to alleviate the adverse effects of chilling stress on growth and productivity of coriander.
\end{abstract}

\footnotetext{
* Correspondence: m.shehata@sci.asu.edu.eg

'Department of Botany, Faculty of Science, Ain Shams University, Cairo

11355, Egypt

Full list of author information is available at the end of the article
}

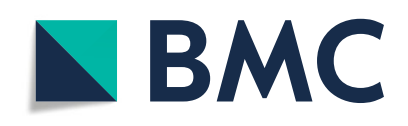

(c) The Author(s). 2021 Open Access This article is licensed under a Creative Commons Attribution 4.0 International License, which permits use, sharing, adaptation, distribution and reproduction in any medium or format, as long as you give appropriate credit to the original author(s) and the source, provide a link to the Creative Commons licence, and indicate if changes were made. The images or other third party material in this article are included in the article's Creative Commons licence, unless indicated otherwise in a credit line to the material. If material is not included in the article's Creative Commons licence and your intended use is not permitted by statutory regulation or exceeds the permitted use, you will need to obtain permission directly from the copyright holder. To view a copy of this licence, visit http://creativecommons.org/licenses/by/4.0/ The Creative Commons Public Domain Dedication waiver (http://creativecommons.org/publicdomain/zero/1.0/) applies to the data made available in this article, unless otherwise stated in a credit line to the data. 
Conclusions: It could be suggested that the inducing effect of the pretreatments on hormonal balance triggered an increase in IAA $+G A_{3} / A B A$ hormonal ratio. This ratio could be linked and engaged with the protection of cellular metabolic activities from chilling injury against the whole plant life cycle. Therefore, it was speculated that seed priming in humic acid is a powerful technique that can benefit the chilled along with non-chilled plants and sustain the economic importance of coriander plant productivity.

Keywords: Low temperature stress, Coriandrum sativum L., Growth biostimulators, Growth hormones, Antioxidants, RuBisCO complex integrity, HDN-PAGE

\section{Background}

Generally, chilling has been defined as that under low atmospheric temperatures no ice formed inside plant tissues. It has been previously reported that plant species subjected to low temperature emerged as one of the serious problems. This problem was reported previously by Wang et al. [99] in tropical and subtropical plants due to a sudden change in temperature. Chilling has a serious impact on the growth and production of commercial crop plants marked as sensitive to chilling like tomato, maize, cotton, pepper, soybean, rice, and affects tropical and subtropical fruits like bananas, papayas, mangoes, grapes, and oranges [86]. Furthermore, low-temperature results in a physiological disturbance known as chilling injury. Various plant developmental and physiological processes (like crop growth, cell division, photosynthesis, water transport, lipids, metabolites, and yield) are negatively affected by this injury [32, 59].

Coriander (Coriandrum sativum L.) is a Mediterranean famous herb that belongs to family Apiaceae (Umbelliferae) and characterized by its essential oils used in food industries. Also, coriander is considered as an essential ingredient in curry powder, pharmaceutical and medicinal industry, and cosmetics. Coriander is also well known for its antioxidant, anti-diabetic, antimutagenic, anti-anxiety and antimicrobial activity along with analgesic and hormone balancing effect. Furthermore, coriander is famous by containing many essential oil active compounds primarily monoterpenes, pinene, limpene, ý-terpinene, p-cymene, borenol, citronellol, camphor, geraniol, coriandrin, dihydrocoriandrin, coriandrons A-E, and, flavonoids. These components help in removing toxic mineral residues such as mercury and lead [54]. Coriander seeds, leaves, and roots are edible, possessing light and fresh distinct flavor. Fresh leaves and ripe fruits are mainly used for culinary purposes. The plant leaves are rich source of vitamins, while seeds are rich in polyphenols and essential oils [79]. The fruit contains $50 \%$ linalool composition used in pharmaceuticals (as good source of $\alpha$-tocopherol and vitamin A), in cosmetic and hygienic industries, and in food and drug industries [79]. The previously mentioned coriander benefits have prompted us to focus our study on this valuable herb particularly the influence of low temperature (chilling) environmental factor on the coriander productivity.

Recently, regulation of the metabolic pathways was practiced in application of biostimulants, such as 2,4dichlorophenoxyacetic acid exploited as stimulant in mango fruits, to enhance acclimation and tolerance in coriander subjected to chilling stress [98]. The silicon effect was reported as beneficial for protecting many plants from biotic or abiotic stresses [60]. Many investigations of primed plants with silicon have recorded greater membrane stability index under stress [56]. The value of potassium silicate was as important a nutritional supplement of both silicon and potassium, which are involved in improving the morphological characters of plants [25]. Humic acid (HA) is a derived acid from soil organic matter and originated from plants, microbes, carbohydrates, proteins, and lignin. HA is the major component of humic substance and is extractable in alkali soil media [96]. In addition, HA possess a powerful impact on improving soil fertility and facilitating root uptake by regulating their function and structure under normal or abiotic stress $[16,96]$. The chemical structure of HA enhances chelation of soil minerals and increased acquisition of nutrients by plants [73]. Previous studies have demonstrated that HA derivatives get firmly attached to the root, aggregate on the cell wall, and solubilize quickly in the cell cytoplasm within few hours of treatment before moving upwards to the shoot [16]. Gamma radiation is also known as ionizing radiation that reacts with atoms and molecules inside the cells to produce free radicals. However, production of free radicals is dependent on the irradiation dose and likely causes damage or modification of components in plants, and ultimately affects the morphology, physiology, anatomy, and biochemistry of plants [7]. As a result, gamma alters photosynthesis, expansion of thylakoid membrane, accumulation of phenolic compounds, and variation of the antioxidative system [7]. It was reported that previously fertilized rice with silicon has grown better after exposure to gamma rays [61, 62].

Moreover, medicinal plants subjected to 50-Gy gamma irradiation had the maximal beneficial effects on stress acclimation, improvements in germination and growth/ yield parameters, and active ingredients enhancement $[6$, 
$22,89]$. In addition, gamma irradiation was used for decontamination in medicinal plants $[28,35]$. In the same context, application of low doses of gamma radiation (20-60 Gy) on chilled-primed Apium graveolence (L.) seeds, either at room temperature or at $5^{\circ} \mathrm{C}$, were effective in alleviating chilling stress by stimulating celery growth and proliferation [26]. Hereby, the aim of this study was to evaluate the ameliorative effect(s) of potassium silicate, HA, and gamma radiation on acclimation of coriander to tolerate chilling stress by recording the data of growth, yield, physiological and molecular aspects.

\section{Results}

For sake of clarity and concise focus throughout showing the obtained results, the percentage of increase/decrease was calculated from the statistically analyzed represented data in the shown tables. The percentage of increase/decrease was calculated as an increase/decrease percentage value in accordance with the control value. This percentage value was calculated by subtracting the value of control reading from the reading value of any physiological treatment, then the result was divided by the reading of control value, and finally, the result is multiplied by 100 . The experimental protocol is presented and listed in Table 1.

\section{Growth parameters}

When compared with non-treated coriander plants, chilling stress caused a significant inhibition in all growth parameters (shoot and root lengths, fresh and dry weights of shoot and root, number of leaves/plant, number of branches/plant, leaves area/plant, and no. of inflorescences/plant) throughout experimental duration (Table 2). Generally, all growth parameters were stimulated by soaking seeds in potassium silicate, HA or exposed to $\gamma$-rays as compared with control and chillingstressed coriander plants at the vegetative stage (Table 2). The most effective treatment was HA alone in both control and stress alleviated samples. At the flowering stage (Fig. S1 and Table 3), chilling stressed and alleviated coriander samples by HA treatment have recorded a significant increase in growth parameters (full length figure is attached as Fig. S1) evaluated by 29.03, 8.94, 91.6, 208.5, 216.1, 178.8, 132.3, 100, 402.9, and 80\% respectively, more than chilling stressed samples (Table 3 ). The same parameters were increased over their corresponding control plants by $12.5,15.6 \%, 56.5,103.9$, $218.4,68.3 \%, 34.4,36.4,82.7,28.6 \%$ for shoot length, root length, fresh and dry weights of shoot and root, number of leaves per plant, number of branches per plant, leaves area per plant, and no. of inflorescences per plant, respectively.

\section{Yield components}

In comparison with non-treated coriander plants, chilling stress $\left(6^{\circ} \mathrm{C} \pm 0.5\right)$ induced significant decrease in yield components (c.a. number of fruits/plant, number of seeds/plant, weight of seeds/plant, and weight of 1000 seeds) as shown in Table 4. Among the different treatments, it has been found that, the number of fruits and seeds, seeds weight/plant, and weight of 1000 seeds were all increased. The superior treatment, in enhancing and improving fruits and seeds development within chilling and non-chilling conditions, was HA followed by silicate and $\gamma$-radiation. Hereby, HA most likely has triggered the highest ameliorative effect on fruits and seeds number/plant (Table 4). Also, pre-soaking treated coriander seeds in silicate, HA, or $\gamma$-radiation have caused improvement of the seed index as compared with control and stressed coriander plants. The best treatment that caused the highest quality and improved seeds yield was HA alone or in combination with chilling. Moreover, seeds quality was improved by 73.3 and $92.92 \%$ over those of the control and chilling-stressed plants, respectively (Table 4). Therefore, HA application was the best to alleviate the impact of chilling stress.

\section{Endogenous phytohormones}

Chilling stress has induced a significant decrease in the growth promoting substances (IAA and $\mathrm{GA}_{3}$ ) levels by

Table 1 Experimental protocol of coriander seeds primed using tap water, solutions of potassium silicate (80 mM) or humic acid (50 mg. $\mathrm{L}^{-1}$ ) or irradiated by (50 Gy) $\mathrm{Y}$-rays

\begin{tabular}{|c|c|c|c|}
\hline No. & Treatment & Seed treatment & Seed protocol prior sowing \\
\hline 1 & Control & Primed in water, non-chilled & $16 \mathrm{~h}$ in non-chilled water $20^{\circ} \mathrm{C} \pm 2$ \\
\hline 2 & Chilling $\left(6^{\circ} \mathrm{C} \pm 0.5\right)$ & Primed in water, chilled & $16 \mathrm{~h}$ in chilled water $6^{\circ} \mathrm{C} \pm 0.5$ \\
\hline 3 & Pot. silicate $(80 \mathrm{mM})$ & primed, non-chilled & $16 \mathrm{~h}$ in non-chilled pot. Silicate \\
\hline 4 & Humic acid (50 $\mathrm{mg} \mathrm{l}^{-1}$ ) & primed, non-chilled & $16 \mathrm{~h}$ in non-chilled HA \\
\hline 5 & $\mathrm{P}$ - rays $(50 \mathrm{~Gy})$ & primed, non-chilled & $16 \mathrm{~h}$ in non-chilled water and $\gamma$-irradiated seeds \\
\hline 6 & Chilling + Pot. silicate & primed, chilled & $16 \mathrm{~h}$ in chilled pot. Silicate \\
\hline 7 & Chilling + Humic acid & primed, chilled & $16 \mathrm{~h}$ in chilled HA \\
\hline 8 & Chilling $+\gamma$ - rays & primed, chilled & $16 \mathrm{~h}$ in chilled water and $\gamma$-irradiated seeds \\
\hline
\end{tabular}


Table 2 Impact of alleviation treatments on growth parameters of chilling-stressed coriander plants at the vegetative stage. Coriander control plants and chilling-stressed ones were subjected to pot. Silicate ( $80 \mathrm{mM}), \mathrm{HA}\left(50 \mathrm{mgl}^{-1}\right.$ ) or $\mathrm{Y}^{-\mathrm{radiation}}$ (50 Gy). The shown data was extracted by using 3 biological and 3 technical replicates. Each biological replicate is comprised of 10 plants (one pot). The mean value of each biological replicate represents the value of one technical replicate. The readings of the 3 technical replicates were recorded. The mean value of the technical replicates was used to calculate $\pm \mathrm{SE}$. Also, the least significant differences (LSD) at 5\% level were calculated to compare the means of different treatments according to Snedecor and Cochran [92]. The values with the same letter are not significantly different $(P<0.05)$. The raw data set of the technical replicates was attached as a supplementary file

\begin{tabular}{|c|c|c|c|c|c|c|c|c|c|}
\hline $\begin{array}{l}\text { Growth } \\
\text { Parameters } \\
\text { Treatment }\end{array}$ & $\begin{array}{l}\text { Shoot } \\
\text { length }(\mathrm{cm})\end{array}$ & $\begin{array}{l}\text { No. of } \\
\text { leaves/ } \\
\text { plant }\end{array}$ & $\begin{array}{l}\text { No. of } \\
\text { branches/ } \\
\text { plant }\end{array}$ & $\begin{array}{l}\text { Leaves } \\
\text { area/plant } \\
(\mathrm{cm})^{2}\end{array}$ & $\begin{array}{l}\text { F. wt. of } \\
\text { shoot }(g)\end{array}$ & $\begin{array}{l}\text { D. wt. of } \\
\text { shoot (g) }\end{array}$ & $\begin{array}{l}\text { Root } \\
\text { length } \\
(\mathrm{cm})\end{array}$ & $\begin{array}{l}\text { F. wt. of } \\
\text { root }(g)\end{array}$ & $\begin{array}{l}\text { D. wt. of } \\
\text { root }(g)\end{array}$ \\
\hline Control & $11.57 \pm 0.23^{d}$ & $16.00 \pm 0.57^{e}$ & $5.67 \pm 0.33^{a}$ & $30.53 \pm 0.34^{e}$ & $0.55 \pm 0.06^{e}$ & $0.09 \pm 0.004^{b c}$ & $6.43 \pm 0.47^{b c}$ & $0.046 \pm 0.005^{f}$ & $0.012 \pm 0.001^{c}$ \\
\hline $\begin{array}{l}\text { Chilling } \\
\left(6^{\circ} \mathrm{C} \pm 0.5\right)\end{array}$ & $10.23 \pm 0.14^{\mathrm{e}}$ & $10.67 \pm 0.88^{f}$ & $3.67 \pm 0.33^{b}$ & $14.28 \pm 0.7^{f}$ & $0.28 \pm 0.02^{e}$ & $0.04 \pm 0.003^{c}$ & $6.20 \pm 0.15^{c}$ & $0.032 \pm 0.002^{9}$ & $0.006 \pm 0.0005^{d}$ \\
\hline $\begin{array}{l}\text { Pot. silicate } \\
(80 \mathrm{mM})\end{array}$ & $17.40 \pm 0.3^{a}$ & $27.67 \pm 1.4^{\mathrm{cd}}$ & $6.00 \pm 0.57^{a}$ & $94.27 \pm 0.83^{b}$ & $0.74 \pm 0.08^{\text {de }}$ & $0.13 \pm 0.003^{b c}$ & $6.63 \pm 0.3^{b c}$ & $0.064 \pm 0.002^{e}$ & $0.016 \pm 0.002^{c}$ \\
\hline $\begin{array}{l}\text { Humic acid } \\
\left(50 \mathrm{mg} \mathrm{l}^{-1}\right)\end{array}$ & $18.10 \pm 0.5^{a}$ & $34.33 \pm 0.9^{a}$ & $7.00 \pm 0.57^{a}$ & $106.12 \pm 2^{a}$ & $2.034 \pm 0.014^{a}$ & $0.21 \pm 0.002^{a b}$ & $7.73 \pm 0.08^{a}$ & $0.131 \pm 0.006^{\mathrm{a}}$ & $0.024 \pm 0.0004^{a}$ \\
\hline - rays (50 Gy) & $17.57 \pm 0.23^{a}$ & $32.67 \pm 1.5^{a b}$ & $7.00 \pm 0.57^{a}$ & $89.64 \pm 1.4^{b}$ & $1.18 \pm 0.16^{b c}$ & $0.20 \pm 0.008^{a b}$ & $7.37 \pm 0.4^{\mathrm{ab}}$ & $0.126 \pm 0.01^{a}$ & $0.022 \pm 0.003^{a}$ \\
\hline $\begin{array}{l}\text { Chilling + Pot. } \\
\text { silicate }\end{array}$ & $14.33 \pm 0.44^{c}$ & $30.00 \pm 0.57 d$ & $6.33 \pm 0.66^{a}$ & $57.39 \pm 1.1^{d}$ & $1.22 \pm 0.14^{b c}$ & $0.30 \pm 0.11^{b c}$ & $7.40 \pm 0.3^{a b}$ & $0.089 \pm 0.006^{d}$ & $0.014 \pm 0.0012^{c}$ \\
\hline $\begin{array}{l}\text { Chilling + Humic } \\
\text { acid }\end{array}$ & $15.77 \pm 0.15^{b}$ & $23.67 \pm 2.9^{b c}$ & $6.00 \pm 0.67^{a}$ & $71.82 \pm 1.5^{c}$ & $0.97 \pm 0.013^{b}$ & $0.12 \pm 0.003^{\mathrm{a}}$ & $7.97 \pm 0.4^{a}$ & $0.106 \pm 0.004^{b}$ & $0.022 \pm 0.0004^{\mathrm{a}}$ \\
\hline Chilling $+\gamma$ - rays & $15.50 \pm 0.28^{b}$ & $25.00 \pm 0.57^{d}$ & $7.00 \pm 0.57^{a}$ & $59.34 \pm 3.3^{d}$ & $1.23 \pm 0.05^{c d}$ & $0.17 \pm 0.007^{\mathrm{abc}}$ & $6.67 \pm 0.24^{b c}$ & $0.096 \pm 0.005^{c}$ & $0.0164 \pm 0.0015^{b c}$ \\
\hline LSD at 0.05 & 0.877 & 4.227 & 1.598 & 4.744 & 0.2597 & 0.136 & 0.994 & 0.0055 & 0.0055 \\
\hline
\end{tabular}

$40.68,42.03 \%$, respectively and significant increase in the growth inhibitor ABA level by $316.6 \%$ as compared with control plants (Table 5). All applied treatments either separately or in combination with chilling stress have induced marked increases in both IAA and $\mathrm{GA}_{3}$ contents. The maximum increases in IAA (104.52\%) and $\mathrm{GA}_{3}$ were obtained in chilling-stressed samples alleviated by HA as compared by other chilling-treatments (Table 5). On the other hand, ABA content was increased upon chilling stress and decreased particularly after HA subsequent treatment. Treatment by $\gamma$-radiation has led to ABA increase in control coriander. Furthermore, sole treatment by $\gamma$-radiation has led to ABA increase in coriander leaves. In addition, chilling stress has caused a marked decrease in $\mathrm{IAA}+\mathrm{GA}_{3} / \mathrm{ABA}$ ratio, while soaking coriander seeds in pot. Silicate, HA, or irradiation with $\gamma$-rays has induced a reverse pattern in this ratio as compared with chilling-stressed samples. It was found that the maximum peak of such response was obtained by alleviation of the chilling stress by HA application (Table 5).

\section{Changes in photosynthetic pigments and carbohydrates content}

Chilling stress caused a pronounced decrease in chl a, chl b, and consequently the total chlorophylls below those detected in control coriander leaves. All applied treatments have induced a marked increase in chl a, chl b, and total chlorophylls in stressed samples (Table 6). The maximum alleviated impact was achieved by individual treatment of HA or HA combined with chilling when compared with chilling-stressed coriander samples. Chilling stress has induced an increase in (chl a/ chl $b$ ) ratio more than control plants. Furthermore, all applied treatments have triggered a marked increase in (chl $a / \mathrm{chl} b$ ) ratio in relation to control. Chilling stress combined with different stimulator elements (Pot. silicate, $\mathrm{HA}$, and $\gamma$-irradiation) have recorded an increase in (chl $a / \mathrm{chl} b$ ) ratio in control and chilling stress leaves. The maximum values 2.14 were achieved by chilling plus Pot. silicate and chilling plus HA which increased by 20.90 and $12.04 \%$ more than control and chilling-stressed leaves, respectively. On the other hand, the soluble sugars were increased significantly in chilling stressed plants, particularly under the effect of HA treatment compared with control values. All applied treatments- Pot. silicate, $\mathrm{HA}$, or gamma radiation- either separately or in combination with chilling stress have increased the soluble sugars content of coriander leaves as compared with untreated control plant (Table 6). The most pronounced effect was recorded in HA application. The latter treatment was considered as the best enhancer for soluble sugars in chilling stressed coriander by $40 \%$ higher than control samples, followed by gamma radiation and Pot. silicate application. Polysaccharide contents were 


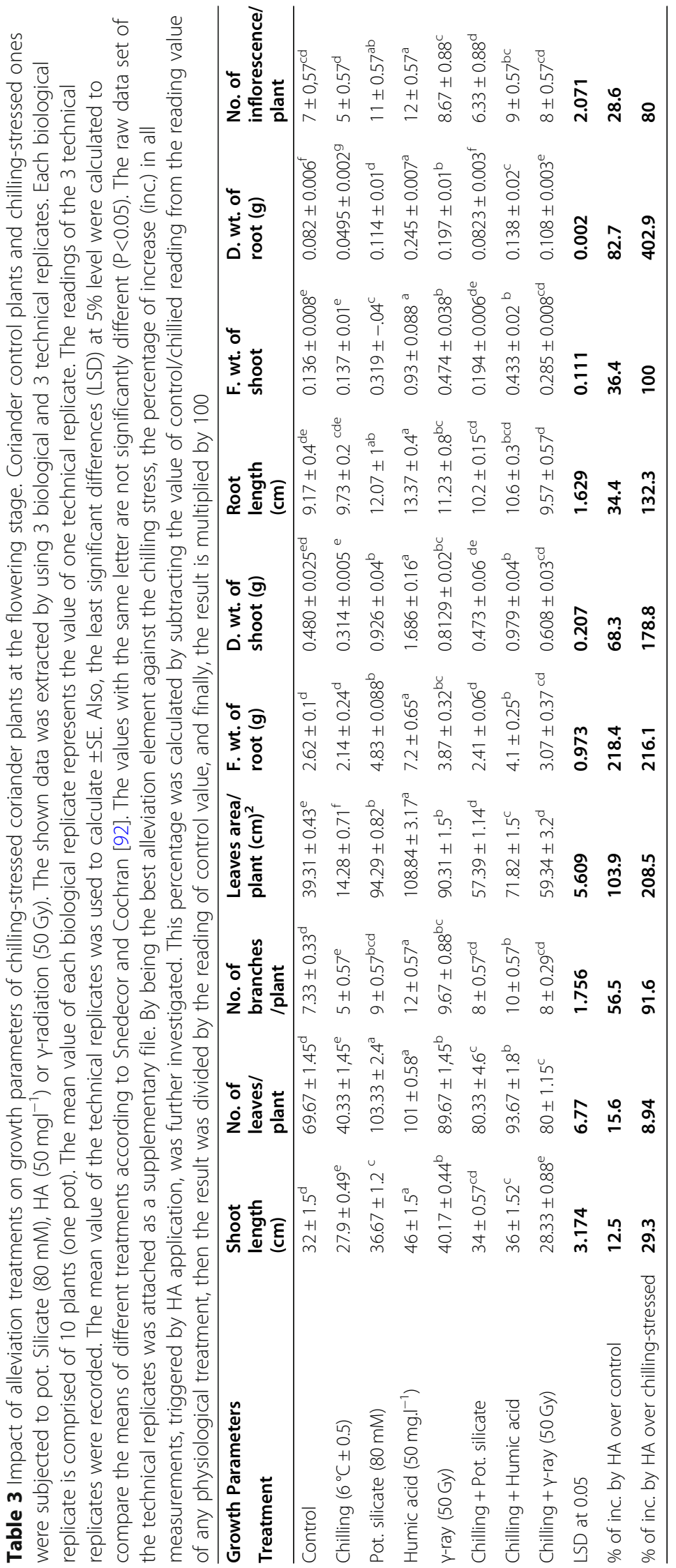




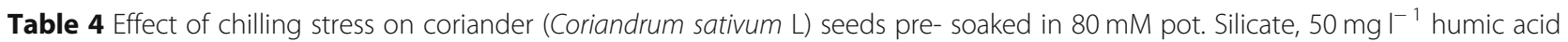
or soaked in water after exposure to $y$-rays (50 Gy) and the interaction of the alleviation treatments and chilling stress on the yield components. The shown data was extracted by using 3 biological and 3 technical replicates. Each biological replicate is comprised of 10 plants (one pot). To perform the biochemical analysis, the combined tissue of these ten plants (one pot content) refers to one technical replicate. The readings of the 3 technical replicates were recorded. Sample extraction was done solely for each technical replicate. The mean of the values was used to calculate \pm SE. Also, the least significant differences (LSD) at 5\% level were calculated to compare the means of different treatments according to Snedecor and Cochran [92]. The values with the same letter are not significantly different $(P<0.05)$. The raw data set of the technical replicates was attached as a supplementary file

\begin{tabular}{|c|c|c|c|c|}
\hline $\begin{array}{l}\text { Yield component } \\
\text { Treatment }\end{array}$ & $\begin{array}{l}\text { No. of fruits/ } \\
\text { plant }\end{array}$ & $\begin{array}{l}\text { No. of } \\
\text { seeds/plant }\end{array}$ & $\begin{array}{l}\text { Weight of } \\
\text { seeds/ } \\
\text { plant } \\
\text { (g) }\end{array}$ & $\begin{array}{l}\text { Seed index } \\
\text { (weight of } \\
1000 \text { seeds } \\
\text { (g)) }\end{array}$ \\
\hline Control & $119.0 \pm 5.7^{9}$ & $238 \pm 5.8^{9}$ & $0.56 \pm 0.08^{9}$ & $2.36 \pm 0.08^{f}$ \\
\hline Chilling $\left(6^{\circ} \mathrm{C} \pm 0.5\right)$ & $77.65 \pm 1.14^{h}$ & $155.3 \pm 1.15^{h}$ & $0.32 \pm 0.01^{h}$ & $2.12 \pm 0.012^{9}$ \\
\hline Pot. silicate ( $80 \mathrm{mM})$ & $523.50 \pm 13.3^{b}$ & $1047 \pm 13^{b}$ & $4.08 \pm 0.2^{b}$ & $3.9 \pm 0.2^{b}$ \\
\hline Humic acid $\left(50 \mathrm{mg}^{-1} \mathrm{l}\right)$ & $590.00 \pm 5.7^{\mathrm{a}}$ & $1180 \pm 5.6^{a}$ & $5.73 \pm 0.08^{\mathrm{a}}$ & $4.86 \pm 0.077^{a}$ \\
\hline Y-rays (50 Gy) & $473.65 \pm 21.8^{c}$ & $947.3 \pm 1.15^{c}$ & $2.48 \pm 0.15^{e}$ & $2.62 \pm 0.15^{e}$ \\
\hline Chilling + Pot. silicate & $409.65 \pm 6.7^{\mathrm{e}}$ & $819.3 \pm 13.3^{e}$ & $2.91 \pm 0.08^{d}$ & $3.56 \pm 0.075^{c}$ \\
\hline Chilling + Humic acid & $446.00 \pm 48.6^{d}$ & $892 \pm 13.3^{d}$ & $3.65 \pm 0.18^{c}$ & $4.09 \pm 0.19^{b}$ \\
\hline Chilling $+\gamma$-rays & $303.00 \pm 5^{f}$ & $606 \pm 5.7^{f}$ & $1.81 \pm 0.17^{f}$ & $2.99 \pm 0.16^{d}$ \\
\hline LSD at 0.05 & 27.62 & 27.62 & 0.2072 & 0.2072 \\
\hline
\end{tabular}

decreased under chilling stress and increased in treated coriander alleviated with silicate and HA in both stressed and control coriander. However, the increase of total carbohydrates level was taken place by HA pretreatment in the control and alleviated chilling stressed coriander with silicate and HA (Table 6). It was worthy to mention that although individual gamma radiation has increased carbohydrates values over chilling stress condition, it was not the best in terms of chilling stress alleviation through carbohydrates protection and restoration compared to HA and silicate treatments (Table 6). Gamma rays' impact on carbohydrates might be described as intermediate between HA and pot. Silicate effects.

Table 5 Effect of chilling stress on coriander (Coriandrum sativum L.) seeds pre- soaked in $80 \mathrm{mM}$ pot. Silicate, 50 mg I ${ }^{-1}$ humic acid or soaked in water after exposure to $\gamma$-rays ( $50 \mathrm{~Gy})$ and the interaction of the alleviation treatments and chilling stress on endogenous phytohormones ( $\mu \mathrm{g} / 100 \mathrm{~F}$. wt.) at flowering stage. The shown data was extracted by using 3 biological and 3 technical replicates. Each biological replicate comprised of 10 plants (one pot). To perform the biochemical analysis, the combined tissue of these ten plants refers to one technical replicate. The readings of the 3 technical replicates were recorded. Sample extraction was done solely for each technical replicate. The mean of the values was used to calculate \pm SE. Also, the least significant differences (LSD) at 5\% level were calculated to compare the means of different treatments according to Snedecor and Cochran [92]. The values with the same letter are not significantly different $(P<0.05)$. The raw data set of the technical replicates was attached as a supplementary file

\begin{tabular}{|c|c|c|c|c|}
\hline $\begin{array}{l}\text { phytohormone } \\
\text { Treatment }\end{array}$ & IAA & $\mathrm{GA}_{3}$ & $A B A$ & $\begin{array}{l}\text { IAA + } \\
\mathrm{GA}_{3} / \\
\mathrm{ABA}\end{array}$ \\
\hline Control & $7.08 \pm 0.05^{e}$ & $390.00 \pm 17.3^{e}$ & $1.75 \pm 0.43^{h}$ & 226.51 \\
\hline Chilling $\left(6^{\circ} \mathrm{C} \pm 0.5\right)$ & $4.20 \pm 0.12^{f}$ & $226.10 \pm 17.3^{h}$ & $7.29 \pm 0.43^{b}$ & 31.61 \\
\hline Pot. silicate (80 mM) & $13.20 \pm 0.69^{b}$ & $405.51 \pm 17.3^{c}$ & $3.90 \pm 0.43^{e}$ & 107.4 \\
\hline Humic acid $\left(50 \mathrm{mg} \mathrm{l}^{-1}\right)$ & $15.54 \pm 0.69^{\mathrm{a}}$ & $443.43 \pm 17.3^{\mathrm{a}}$ & $4.07 \pm 0.43^{d}$ & 112.7 \\
\hline$Y$ - rays (50 Gy) & $10.86 \pm 0.69^{d}$ & $390.86 \pm 17.3^{d}$ & $7.74 \pm 0.43^{\mathrm{a}}$ & 51.9 \\
\hline Chilling + Pot. silicate & $6.24 \pm 0.69^{e}$ & $326.93 \pm 17.3^{f}$ & $3.10 \pm 0.43^{f}$ & 107.27 \\
\hline Chilling + Humic acid & $8.59 \pm 0.69^{d}$ & $423.45 \pm 17.3^{b}$ & $2.44 \pm 0.43^{9}$ & 177.1 \\
\hline Chilling $+\gamma$ - rays & $6.86 \pm 0.69^{e}$ & $255.23 \pm 17.3^{9}$ & $4.38 \pm 0.43^{c}$ & 59.83 \\
\hline LSD at 0.05 & 0.862 & 24.49 & 0.613 & - \\
\hline
\end{tabular}


Table 6 Effect of chilling stress on coriander (Coriandrum sativum L.) seeds pre- soaked in $80 \mathrm{mM}$ pot. Silicate, 50 mg $\mathrm{I}^{-1}$ humic acid or soaked in water after exposure to $\mathrm{\gamma}$-rays (50 Gy) and the interaction of the alleviation treatments and chilling stress on photosynthetic pigments ( $\mu \mathrm{g} / \mathrm{g}$ D. wt. in coriander leaves) and carbohydrate contents (g/100 g D. wt.) at flowering stage. The shown data was extracted by using 3 biological and 3 technical replicates. Each biological replicate comprised of 10 plants (one pot). To perform the biochemical analysis, the combined tissue of these ten plants refers to one technical replicate. Sample extraction was done solely for each technical replicate. The readings of the 3 technical replicates were recorded. The mean of the values was used to calculate \pm SE. Also, the least significant differences (LSD) at 5\% level were calculated to compare the means of different treatments according to Snedecor and Cochran [92]. The values with the same letter are not significantly different $(P<0.05)$. The raw data set of the technical replicates was attached as a supplementary file

\begin{tabular}{|c|c|c|c|c|c|c|c|}
\hline \multirow{2}{*}{$\begin{array}{l}\text { Pigment/Carbohydrate } \\
\text { Treatment }\end{array}$} & \multicolumn{4}{|c|}{ Photosynthetic pigments } & \multicolumn{3}{|c|}{ Carbohydrate fractions } \\
\hline & $\mathrm{Chl} \mathrm{a}$ & $\mathrm{Chl} \mathrm{b}$ & $\mathrm{Chl} \mathrm{a/b}$ & Total Chl & Soluble Sugars & Polysaccharides & Total Carbohydrates \\
\hline$\overline{\text { Control }}$ & $13.12 \pm 0.01^{\mathrm{e}}$ & $7.43 \pm 0.13^{b}$ & $1.77 \pm 0.03$ & $20.55 \pm 0.15^{\mathrm{bc}}$ & $2.26 \pm 0.05^{e}$ & $14.39 \pm 0.88^{c}$ & $16.65 \pm 0.9^{\text {cd }}$ \\
\hline Chilling $\left(6^{\circ} \mathrm{C} \pm 0.5\right)$ & $9.72 \pm 0.16^{9}$ & $5.1 \pm 0.2^{d}$ & $1.91 \pm 0.11$ & $14.82 \pm 0.05^{d}$ & $2.9 \pm 0.049^{\mathrm{cd}}$ & $9.46 \pm 0.36^{\mathrm{e}}$ & $12.36 \pm 0.3^{e}$ \\
\hline Pot. silicate (80 mM) & $15.12 \pm 0.35^{b}$ & $7.9 \pm 0.005^{b}$ & $1.91 \pm 0.04$ & $23.02 \pm 0.36^{b}$ & $3.59 \pm 0.11^{\mathrm{ab}}$ & $19.17 \pm 1.07^{\mathrm{a}}$ & $22.76 \pm 1.1^{\mathrm{a}}$ \\
\hline Humic acid $\left(50 \mathrm{mgl}^{-1}\right)$ & $17.50 \pm 0.18^{a}$ & $9.53 \pm 0.02^{\mathrm{a}}$ & $1.84 \pm 0.01$ & $27.03 \pm 0.12^{a}$ & $4.06 \pm 0.06^{\mathrm{a}}$ & $21.57 \pm 0.34^{a}$ & $25.16 \pm 0.3^{a}$ \\
\hline$\gamma$ - rays (50 Gy) & $14.86 \pm 0.21^{b c}$ & $7.91 \pm 0.12^{b}$ & $1.88 \pm 0.05$ & $22.77 \pm 0.18^{b}$ & $2.49 \pm 0.19^{\mathrm{de}}$ & $16.32 \pm 0.5^{b}$ & $18.81 \pm 0.3^{b}$ \\
\hline Chilling + Pot. silicate & $14.14 \pm 0.36^{d}$ & $6.61 \pm 0.24^{c}$ & $2.14 \pm 0.02$ & $20.75 \pm 0.6^{b c}$ & $2.55 \pm 0.08^{\mathrm{de}}$ & $15.43 \pm 0.59^{b c}$ & $17.97 \pm 0.5^{\mathrm{bc}}$ \\
\hline Chilling + Humic acid & $14.17 \pm 0.12^{\mathrm{cd}}$ & $6.61 \pm 0.05^{c}$ & $2.14 \pm 0.002$ & $20.78 \pm 0.17^{b c}$ & $3.35 \pm 0.32^{\mathrm{bc}}$ & $15.69 \pm 0.6^{b c}$ & $19.04 \pm 0.84^{b}$ \\
\hline Chilling $+\gamma$ - rays & $12.30 \pm 0.08^{f}$ & $5.85 \pm 0.02^{d}$ & $2.10 \pm 0.12$ & $18.15 \pm 0.09^{c}$ & $3.08 \pm 0.06^{\mathrm{cd}}$ & $11.87 \pm 0.22^{d}$ & $14.95 .4 \pm 0.28^{d}$ \\
\hline LSD at 0.05 & 0.72 & 0.59 & 0.067 & 1.55 & 0.418 & 1.966 & 0.006 \\
\hline
\end{tabular}

\section{Changes in antioxidant compounds}

The Changes in antioxidant compounds (ascorbic acid, carotenoids, flavonoids, total Phenols, and Proline) of coriander leaves in response to pre-sowing step with chilling stress (the case of pot. Silicate or HA) or in $\mathrm{H}_{2} \mathrm{O}$ (after exposed to $\gamma$-radiation) and their interaction were shown in Table 7.

Firstly, referred to control value, chilling stress caused a significant decrease in ascorbic acid contents by $46.81 \%$ below control value. In turn, pot. Silicate and HA (separate or in combination with chilling stress) have caused a significant increase in ascorbic acid contents as compared with non-chilling \& chilling-stressed plant. The maximum value obtained from chilled plant primed in HA was increased reached 31.91 and $148 \%$ over non-chilling and chilling control plant, respectively (Table 7). Conversely, exposure of seeds to $\gamma$ - rays caused a decrease in ascorbic acid contents as compared with control plant, but their interaction with chilling stress have induced marked increase in ascorbic acid as compared with chilling-stressed plant. The most effective treatment in alleviating adverse effect of chilling was HA.

Secondly, it was notably detected that chilling in coriander caused a significant decrease in carotenoids content by $45.14 \%$ below of control plants. Pot. silicate, HA, and $\gamma$-radiation and their interaction with chilling stress have induced marked increments in carotenoids content over chilling-stressed plants. The most effective treatment in alleviating adverse effect of chilling was HA followed by silicate individually or in combination with chilling stress (Table 7).
Thirdly, as compared with the control coriander plants, chilling stress has caused a significant increase in flavonoids content by $19.96 \%$ as shown in Table 7 . While, silicate, $\mathrm{HA}$, and $\gamma$ - radiation individually caused significant increments in flavonoids content in relation to non-chilling control. The highest content was obtained by seeds soaked in HA. However, the interaction between different treatments and chilling stress induced significant increments in flavonoid contents as compared with non-chilling or chilling stressed control plants except in $\gamma$-radiation, which decreased flavonoids content significantly when compared to chilled control plants. Therefore, the best treatment that alleviated the harmful effect of chilling was HA then silicate, as both had increased the flavonoids content by 15.41 and $3.33 \%$ over that of chilled coriander plants.

Fourthly, compared with control plants, chilling stress induced increments in total phenolic content by $17.768 \%$ over control coriander plant. Silicate, HA, and $\gamma$-radiation which applied individually and their interactions with chilling stress induced significant increments in total phenol contents as compared with non-chilling control plants. On the other hand, the interaction treatments decreased total phenol except silicate that caused an increase by $3.42 \%$ as compared with chilled plants.

Finally, incubation of coriander seed in water $\left(6^{\circ} \mathrm{C} \pm\right.$ 0.5 ) for $16 \mathrm{~h}$ has increased proline contents by $92.78 \%$ in grown leaves above the control value. Generally, silicate, $\mathrm{HA}$, and gamma irradiation treatments have induced increments in proline content comparing to non-chilling control plants. However, all applied treatments 
Table 7 Effect of chilling stress on coriander (Coriandrum sativum L.) seeds pre-soaked in $80 \mathrm{mM}$ pot. Silicate, $50 \mathrm{mg} \mathrm{I}^{-1}$ humic acid or soaked in water after exposure to $\mathrm{Y}$-rays (50 Gy) and the interaction of the alleviation treatments and chilling stress on antioxidant compounds (ascorbic acid, carotenoids, flavonoids, total phenolics and proline) at flowering stage. The shown data was extracted by using 3 biological and 3 technical replicates. Each biological replicate comprised of 10 plants (one pot). To perform the biochemical analysis, the combined tissue of these ten plants refers to one technical replicate. Sample extraction was done solely for each technical replicate. The readings of the 3 technical replicates were recorded. The mean of the values was used to calculate \pm SE. Also, the least significant differences (LSD) at 5\% level were calculated to compare the means of different treatments according to Snedecor and Cochran [92]. The values with the same letter are not significantly different $(P<0.05)$. The raw data set of the technical replicates was attached as a supplementary file. The percentage of increase (inc.) or decrease (dec.) caused by the chilling stress was investigated. $\downarrow$ Refers to the percentage of decrease and $\mathbf{\uparrow}$ refers to the percentage of increase compared with the control values. By being the best alleviation element against the chilling stress (except for phenolic and proline), the percentage of increase in all measurements, triggered by HA application, was further investigated. This percentage was calculated by subtracting the value of control/chillied reading from the reading value of any physiological treatment, then the result was divided by the reading of control value, and finally, the result is multiplied by 100

\begin{tabular}{|c|c|c|c|c|c|}
\hline $\begin{array}{l}\text { Antioxidant compounds } \\
\text { Treatment }\end{array}$ & $\begin{array}{l}\text { Ascorbic } \\
\text { acid (g/ } \\
100 \mathrm{~g}) \\
\text { D. wt. }\end{array}$ & $\begin{array}{l}\text { Carotenoids } \\
(\mu \mathrm{g} / \mathrm{g}) \\
\text { D. wt. }\end{array}$ & $\begin{array}{l}\text { Flavonoids } \\
\text { (g/100 g) } \\
\text { D. wt. }\end{array}$ & $\begin{array}{l}\text { Phenolic } \\
\text { (g/100 g) } \\
\text { D. wt. }\end{array}$ & $\begin{array}{l}\text { Proline } \\
(\mu \mathrm{g} / 100 \mathrm{~g}) \\
\text { D. wt. }\end{array}$ \\
\hline Control & $0.47 \pm 0.03^{d}$ & $4.63 \pm 0.24^{b}$ & $0.476 \pm 0.04^{h}$ & $0.968 \pm 0.021^{c}$ & $166.3 \pm 2.88^{c}$ \\
\hline Chilling $\left(6^{\circ} \mathrm{C} \pm 0.5\right)$ & $0.25 \pm 0.01^{h}$ & $2.54 \pm 0.16^{c}$ & $0.571 \pm 0.043^{d}$ & $1.14 \pm 0.021^{c}$ & $320.6 \pm 2.88^{b}$ \\
\hline Pot. silicate ( $80 \mathrm{mM})$ & $0.54 \pm 0.01^{c}$ & $6.04 \pm 0.26^{a}$ & $0.563 \pm 0.04^{e}$ & $1.13 \pm 0.021^{d}$ & $242.4 \pm 2.88^{d}$ \\
\hline Humic acid $\left(50 \mathrm{mg} \mathrm{I}^{-1}\right)$ & $0.73 \pm 0.11^{\mathrm{a}}$ & $6.07 \pm 0.11^{\mathrm{a}}$ & $0.686 \pm 0.04^{a}$ & $1.37 \pm 0.021^{\mathrm{a}}$ & $191.1 \pm 2.88^{f}$ \\
\hline Y - rays (50 Gy) & $0.44 \pm 0.18^{f}$ & $5.80 \pm 0.15^{a}$ & $0.498 \pm 0.043^{f}$ & $0.995 \pm 0.015^{e}$ & $228.6 \pm 2.88^{\mathrm{e}}$ \\
\hline Chilling + Pot. silicate & $0.48 \pm 0.01^{d}$ & $5.65 \pm 0.11^{a}$ & $0.59 \pm 0.043^{c}$ & $1.179 \pm 0.045^{b}$ & $326.4 \pm 2.88^{a}$ \\
\hline Chilling + Humic acid & $0.62 \pm 0.01^{b}$ & $5.89 \pm 0.05^{a}$ & $0.659 \pm 0.04^{b}$ & $0.988 \pm 0.021^{f}$ & $277.6 \pm 2.88^{c}$ \\
\hline Chilling $+\gamma-$ rays & $0.37 \pm 0.01^{9}$ & $4.58 \pm 0.12^{\mathrm{ab}}$ & $0.473 \pm 0.04^{h}$ & $0.950 \pm 0.021^{9}$ & $173.0 \pm 2.88^{9}$ \\
\hline LSD at 0.05 & 0.0017 & 0.277 & 0.00175 & 0.00175 & 0.0017 \\
\hline$\%$ of inc./dec. caused by chilling stress compared with control & $\downarrow 46.81$ & $\downarrow 48.79$ & $\uparrow 19.96$ & $\uparrow 46.9$ & $\uparrow 93.95$ \\
\hline$\%$ of inc. caused by HA compared with chilling stress & 148 & 131.89 & 15.41 & - & - \\
\hline
\end{tabular}

decreased the proline contents below those of chilling stressed plant except in case of silicate in combination with chilling stress, which increased their content by $1.81 \%$.

\section{Antioxidant enzymes and lipid peroxidation}

The changes in antioxidants enzymes activities were investigated for primed non-chilled or primed chilled coriander plant using pot. Silicate, $\mathrm{HA}$, and $\mathrm{H}_{2} \mathrm{O}$ after exposure to gamma rays and their interaction are represented in Table 8. All the applied treatments have decreased PPO activity below that of chilling stressed plant, except in plant exposed to $\gamma$-radiation, which has non-significant change. Also, alleviation the chilling stress by pot. Silicate, HA, and $\gamma$-radiation decreased POD activity by $33.46,38.62$, and $53.35 \%$, respectively below the primed chilled plant but its values were still markedly higher than those of control plants by 133.56 , 115.44 , and $63.76 \%$, respectively (Table 8). Conversely, CAT activity in leaves of soaked coriander in HA, or exposed to gamma radiation decreased by 30.79 and $64.90 \%$ as compared with non-chilled plants and by 66.29 and $82.9 \%$ compared to chilled plants. In addition, the interaction between chilled plants and all applied treatments caused a decrease in CAT activity below the control and chilled plant except in silicate and silicate combined with chilled plant, which caused an increase by 57.62 and $14.57 \%$ compared with non-chilled control plants, respectively.

Regarding monitoring lipid peroxidation, estimation of MDA is crucial since MDA was a marker for evaluating lipid peroxidation and damage to plasma lemma or organelle membranes which increases with different environmental stress factors. The result listed in Table 8 revealed that incubation of coriander plant seeds in $6{ }^{\circ} \mathrm{C} \pm 0.5$ induced a marked increase in MDA contents by $84.62 \%$ with respect to control coriander plant. Whereas pre-soaked seeds in pot. Silicate or HA or soaking in water after irradiated by $\gamma$ - rays have induced either significant increase in MDA values as compared with control coriander plants or decrease by $34.45,27.70$ and $37.16 \%$, respectively when compared with chilling stress. Also, the interaction of priming and chilling caused a decrease in value of MDA in relation to chilling stressed plants. The magnitude of such response was more pronounced in gamma radiation followed by HA priming, which decreased by 35.59 and $20.95 \%$, respectively. In general, pot. Silicate, $\mathrm{HA}$, and $\gamma$ - radiation could 
Table 8 Effect of chilling stress on coriander (Coriandrum sativum L.) seeds pre- soaked in $80 \mathrm{mM}$ pot. Silicate, 50 mg I ${ }^{-1}$ humic acid or soaked in water after exposure to $\gamma$-rays (50 Gy) and the interaction of the alleviation elements and chilling stress on antioxidant enzymes PPO, POD, CAT (unit/mg protein) and MDA(nmol/g F. wt.) at flowering stage. The shown data was extracted by using 3 biological and 3 technical replicates. Each biological replicate comprised of 10 plants (one pot). To perform the biochemical analysis, the combined tissue of these ten plants refers to one technical replicate. Sample extraction was done solely for each technical replicate. The readings of the 3 technical replicates were recorded. The mean of the values was used to calculate \pm SE. Also, the least significant differences (LSD) at 5\% level were calculated to compare the means of different treatments according to Snedecor and Cochran [92]. The values with the same letter are not significantly different $(P<0.05)$. The raw data set of the technical replicates was attached as a supplementary file. The percentage of increase (inc.) caused by the chilling stress compared with the control values was investigated. By being the most alleviation element to restore quietly the enzymes steady state concentration (except for POD and MDA), the percentage of decrease compared with the chilling stress values in all measurements triggered by HA application was further investigated. This percentage was calculated by subtracting the value of control/chillied reading from the reading value of any physiological treatment, then the result was divided by the reading of control value, and finally, the result is multiplied by 100

\begin{tabular}{|c|c|c|c|c|}
\hline \multirow{2}{*}{$\begin{array}{l}\text { Antioxidant enzyme/MDA } \\
\text { Treatment }\end{array}$} & \multicolumn{3}{|c|}{ Antioxidants enzyme (unit/mg protein) } & \multirow{2}{*}{$\begin{array}{l}\text { Lipid } \\
\text { peroxidation } \\
\text { (nmol/g } \\
\text { - F. wt.) } \\
\text { MDA }\end{array}$} \\
\hline & PPO & POD & CAT & \\
\hline Control & $5589.2 \pm 115^{\mathrm{cd}}$ & $1.49 \pm 0.12^{e}$ & $0.604 \pm 0.06^{c}$ & $0.481 \pm 0.01^{e}$ \\
\hline Chilling $\left(6^{\circ} \mathrm{C} \pm 0.5\right)$ & $8966.5 \pm 577^{\mathrm{a}}$ & $5.23 \pm 0.12^{a}$ & $1.24 \pm 0.1^{\mathrm{a}}$ & $0.888 \pm 0.03^{\mathrm{a}}$ \\
\hline Pot. Silicate (80 mM) & $6821.5 \pm 58.9^{b}$ & $3.08 \pm 0.12^{\mathrm{bcd}}$ & $0.952 \pm 0.19^{b}$ & $0.582 \pm 0.02^{\text {cd }}$ \\
\hline Humic acid $\left(50 \mathrm{mg} \mathrm{I}^{-1}\right)$ & $4608.5 \pm 86^{e f}$ & $3.88 \pm 0.42^{b}$ & $0.418 \pm 0.1^{c d}$ & $0.642 \pm 0.02^{b c}$ \\
\hline Y-rays (50 Gy) & $4059.4 \pm 209^{f}$ & $2.95 \pm 0.12^{\mathrm{cd}}$ & $0.212 \pm 0.002^{d}$ & $0.558 \pm 0.019^{\mathrm{de}}$ \\
\hline Chilling + Pot. silicate & $6226.6 \pm 101^{b c}$ & $3.48 \pm 0.69^{b c}$ & $0.692 \pm 0.1^{b c}$ & $0.703 \pm 0.027^{b}$ \\
\hline Chilling + Humic acid & $4996.4 \pm 288^{\text {de }}$ & $3.21 \pm 0.12^{\mathrm{bcd}}$ & $0.596 \pm 0.02^{c}$ & $0.702 \pm 0.024^{b}$ \\
\hline Chilling $+\gamma$-rays & $8234.01 \pm 126^{\mathrm{a}}$ & $2.44 \pm 0.43^{d}$ & $0.212 \pm 0.002^{d}$ & $0.572 \pm 0.026^{\mathrm{cd}}$ \\
\hline LSD at 0.05 & 758 & 0.8964 & 0.2769 & 0.078 \\
\hline$\%$ of inc. in chilling values compared with control & 60.4 & 251 & 106 & 84.61 \\
\hline$\%$ of dec. in Chilling + HA compared chilled plants & 44.3 & 38.6 & 51.93 & 20.94 \\
\hline
\end{tabular}

alleviate the inhibitory effect of chilling stress by decreasing lipid peroxidation below that induced by chilling stress.

\section{Characterization of chilling stress impact on TCPs and expression of chloroplast marker proteins}

TCPs were extracted from control, chilling-stressed, and alleviated biostimulants treated and stressed leaves of 75-days-old coriander plant at vegetative stage. Protein banding profiles of $70-100 \mu \mathrm{g}$ TCPs (equivalent to total protein content) were fractionated using 10\% SDS-PAGE technique (Fig. S2a, b). To manifest the consistency and reproducibility of resulted protein profiles after stress performing and stress-alleviation application, TCPs were extracted from studied samples along with two successive seasons (season 1; Fig. S2a and season 2; Fig. S2b). It was found that the protein band, detected approximately at $53 \mathrm{kDa}$, was identified as $\mathrm{RuBisCO}_{\mathrm{LS}}$ in all samples of control (Fig. S2a, b, Lane 1), stressed (Fig. S2a, b, Lane 2), and chilling-stressed alleviated coriander plants (Fig. S2a, b, Lanes 3-5). Accumulation of RuBisCO $\mathrm{LS}_{\mathrm{LS}}$ was pronounced and negatively affected by applied chilling stress (Fig. 2a). Notably, alleviation of chilling stress by $\mathrm{HA}$ application $\left(50 \mathrm{mgl}^{-1}\right)$ has potentially enhanced and promoted the accumulation of the major pronounced $\mathrm{RuBisCO}_{\mathrm{LS}}$ protein band (Fig. S2a, b). The Expression of RuBisCO $\mathrm{LS}_{\mathrm{LS}}$ protein product was not retrieved, at least to control level, in chilling-stressed coriander plants alleviated by separate and individual application of silicate and gamma irradiation (Fig. S2a, b). Moreover, using of HA as a stress alleviation element has positively induced the expression of unique and characteristic polypeptides running approximately at 45, 48, 65, and $80 \mathrm{kDa}$ more than their corresponding bands in control samples (Fig. S2a, b). In the same context, quantification of RuBisCO $\mathrm{LS}_{\mathrm{LS}}$ protein band, by loading ascending concentrations of protein standard BSA using SDS-PAGE technique, has manifested previous investigations (Fig. 1a; Fig. S2a, b). Band scoring has revealed a percentage of polymorphism by 38.4 and $29.4 \%$ for season 1 and 2, respectively, with a mean of 33.9\%. The generated binary matrix (based on band presence) was used to construct a cluster analysis. Latter analysis was used to find the most relevant samples 

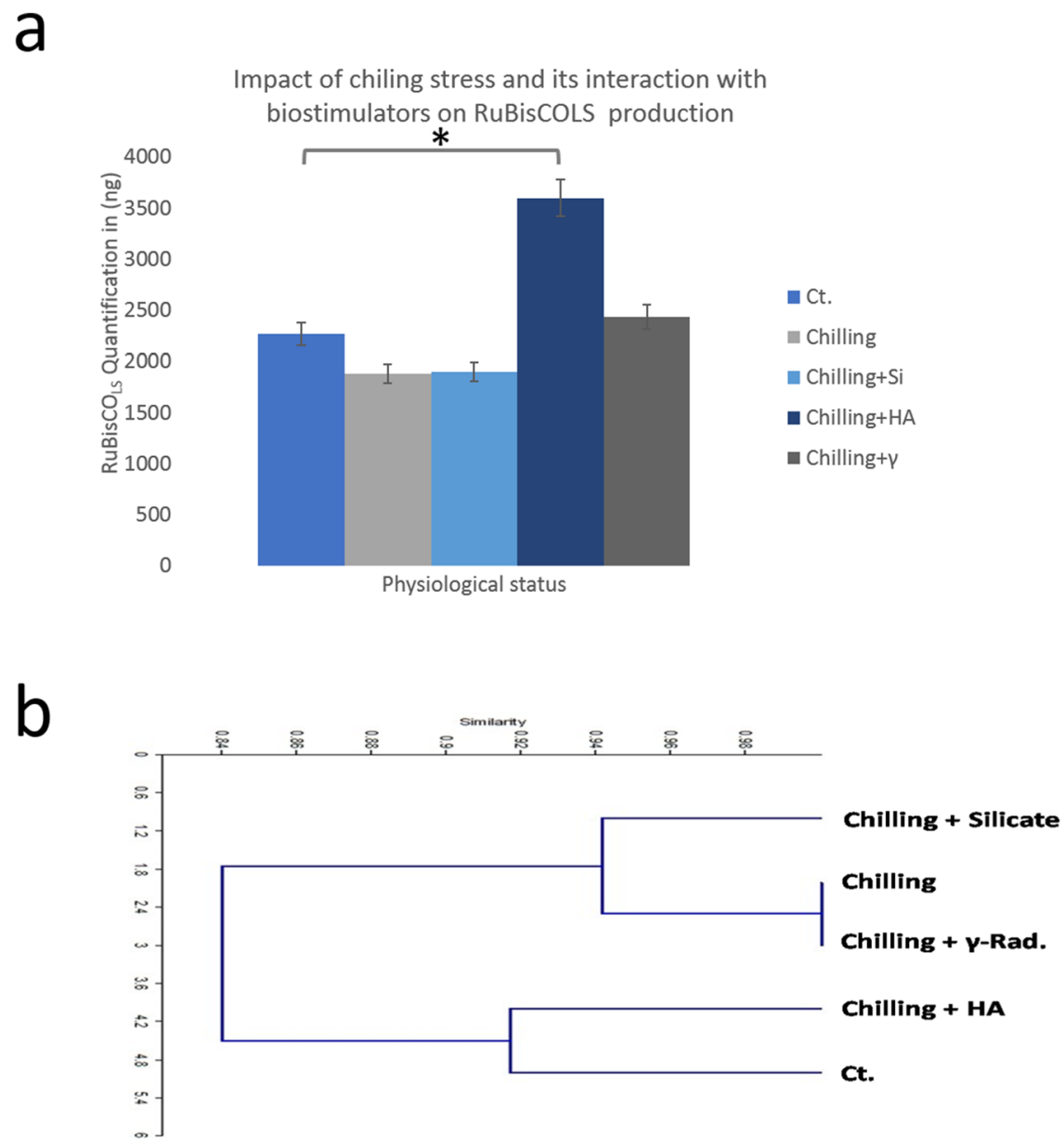

Fig. 1 a) Changes in the steady state expression level of RuBisCO $C_{L S}$ protein. $Y$ axis values indicates the normalized protein production of differentially expressed RuBisCOLS protein in nanograms (ng) of three independent biological replicates and three technical ones. The data were shown as mean \pm s.e.m.; ${ }^{*}, P<0.05$. ImageJ software (IJ 1.46r) was used for image processing and analysis of the electrophoretic running of ascending concentration series of BSA (as protein size standard) to quantify RuBisCO quantification counts were supplement separately. Also, Full-length gels are presented in Supplementary Fig. (2a and b). The data was normalized to the protein band running approximately at $180 \mathrm{kDa}$ as shown in Suppl. Fig. 2a. b) Impact of alleviation treatments on TCPs profiles of chilling-stressed $\left(6^{\circ} \mathrm{C} \pm 0.5\right)$ coriander plants at the vegetative stage (75 days old). Cluster analysis resulted from SDS-PAGE fractionated TCPs as revealed by chilling stress and alleviation treatments to its impact. A dendrogram for the five examined coriander samples was constructed using scored data of fractionated TCPs after chilling stress application and subsequent biostimulants treatments using Unweighed $\underline{\text { Pair-group }} \underline{\text { Method of }}$ Arithmetic mean (UPGMA) and similarity matrices was computed according to Dice coefficient

based on their protein profiles. Notably, control coriander was clustered in one group with stressed samples alleviated by HA treatment (Fig. 1b). On the other hand, the expression of Toc34, Toc75, and eHSP70 were negatively affected by chilling stress; whereas HA treatment was able to maintain, even upregulate, their production (Fig. 2; Fig. S3). The same findings were demonstrated concerning the expression of RubisCO and Toc complexes running approximately at 480 and $700 \mathrm{kDa}$, respectively (Fig. 3; Fig. S4). HA was found to trigger the optimum alleviating impact keeping and promoting the production of both RubisCO and Toc complexes (Fig. 3).

\section{Discussion}

Improvement of the growth parameters and yield components in stressed-alleviated coriander plants

Generally, all growth parameters were stimulated by soaking seed in potassium silicate, HA or exposed to $\gamma$ rays as compared with control and chilling (stressed) coriander plants (Table 2). The most effective treatment was HA alone in both control and chilling- primed samples. In the present study, chilling stress has initiated adversely and inhibitory impact on investigated growth parameters in coriander plant. Reduction in shoot length, branches number/plant, leaves area/plant, root length, fresh and dry weights of shoot and root at 


\section{Physiological status}

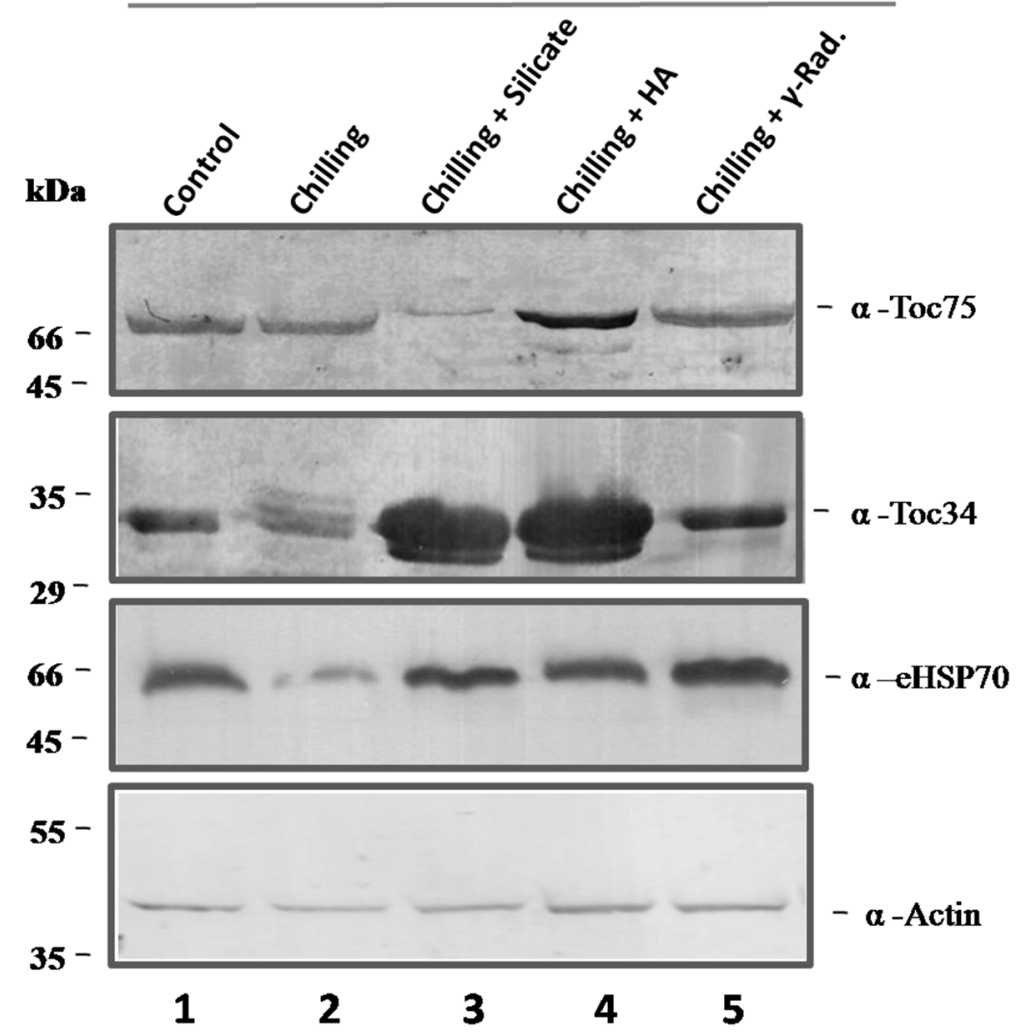

Fig. 2 Immunoblot analysis of the expression of chloroplast marker proteins. Coriander control (Lane 1) and chilling-stressed (Lane 2) ones were subjected to combination of chilling stress in presence of $80 \mathrm{mM}$ Pot. silicate (Lane 3), $50 \mathrm{mg} \mathrm{I}^{-1} \mathrm{HA}$ (Lane 4) or soaked in water after exposed to 50 Gy gamma irradiation (Lane 5). TCPs were extracted and fractionated by SDS-PAGE and immunodecorated against a-Toc34, a-Toc75, eHSP70, and actin primary antibody in a dilution of 1:10,000 as demonstrated in [51]. Cropping of the shown blots was performed properly for sake of clarity and focusing the information. Full-length blots are accompanied the manuscript as Supplementary Fig. 3. Protein extraction procedure for each physiological status (control, chilling stressed, etc.) was performed from the leaves of 3 biological replicates and 3 technical replicates. Each technical replicate represented one biological replicate. Each biological replicate comprises the collection of leaves of 10 plants. The protein extraction was carried out from each technical replicate independently. Finally extracted proteins from the 3 technical replicates were pooled together. Pooled sample were quantified, equally loaded into 10\% SDS-PAGE, and blotted onto PVDF membrane as shown in methods section. Consequently, aliquots of pooled sample were kept as $-80^{\circ} \mathrm{C}$ after the short snap for $30 \mathrm{~s}$ in Liquid Nitrogen

vegetation and flowering stages of plant was observed. As compared with control values, this reduction in growth parameters has been elsewhere reported [29, 32] and could be attributed to decrease in water absorption, altered cell division and cell elongation rates which affect the leaf sizes and weight and reduced ability to close stomata in response to subsequent water deficit [17]. Supply of insufficient water provoked a rapid drop of water potential in leaves during the first hours of cooling. The declining rate of photosynthesis, due to the adverse effect in $\mathrm{CO}_{2}$ assimilation, may weaken the growth through lowering of the rates of both cell division and elongation [4]. Improvement in the growth parameters by increasing of shoot length, fresh and dry weight of shoot and root, leaf area, and branches number/plant (Table 2) were initiated and triggered by using silicate, $\mathrm{HA}$, and gamma rays to alleviate chilling stress. The most effective alleviating element was HA in both control and chilling-stressed samples. The triggered stimulatory impact in growth parameters could be considered as a protective role of silicate, HA, and gamma rays. Silicon was suggested to alleviate chilling stress by deposition in cell wall, increasing its rigidity, and increasing internal storage water within the plant by reducing the water loss, conferring higher growth rates, and, lightening in turn harmful effects of abiotic stress [10]. Also, application of HA was suggested to induce plant growth by acting as a plant growth regulator [80] by the interaction of $\mathrm{HA}$ with the rhizosphere and evolving IAA increasing cell division. The latter promotional 


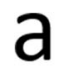

Impact of chiling stress and its interaction with biostimulators on RuBisCO complex production

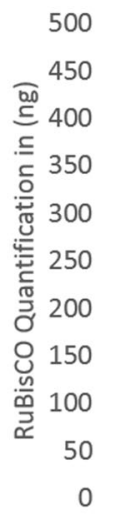

$* *$

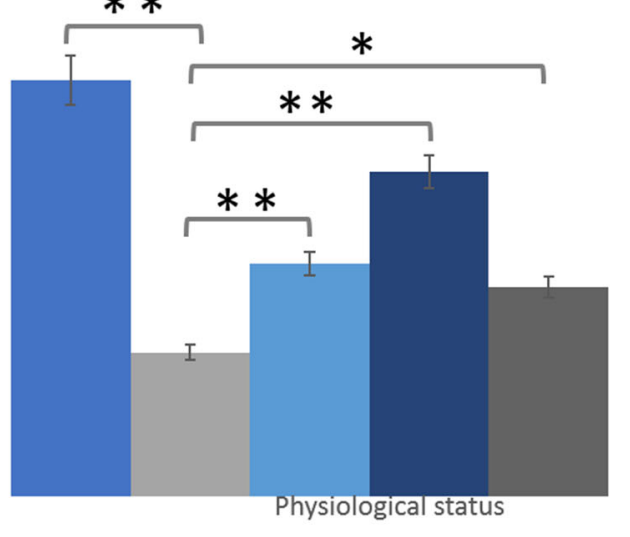

- Ct.

- Chilling

Chilling+Si

- Chilling+HA

- Chilling $+\gamma$

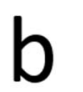

Impact of chiling stress and its interaction with

biostimulators on TOC complex production

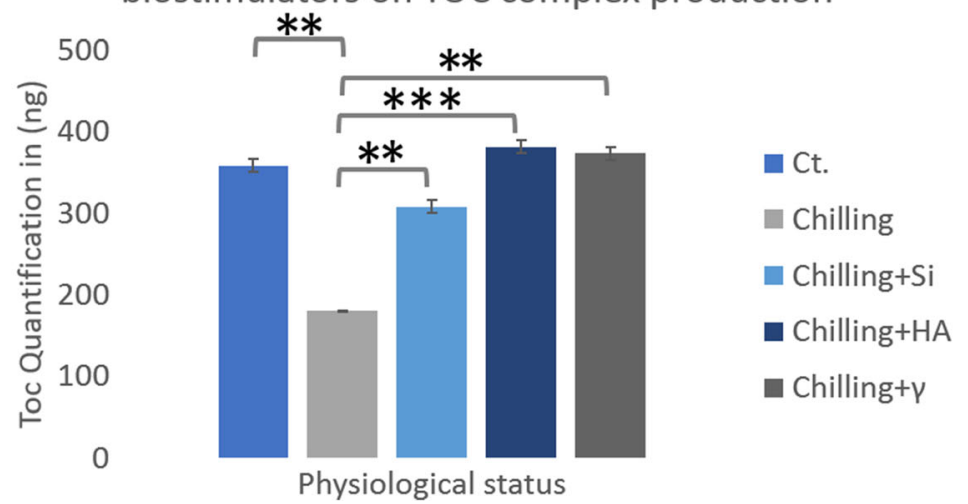

Fig. 3 Changes in the steady state expression level of RuBisCO (panel a) and Toc (panel b) protein complexes. Y axis values indicates the normalized protein production of differentially expressed RuBisCO/Toc complexes in nanograms ( $\mathrm{ng}$ ) of three independent biological experiments and three technical ones. The data were shown as mean \pm s.e.m: $*, P<0.05,{ }^{* *}, P<0.005$, ${ }^{* *}$, and $P<0.0005$. ImageJ software (IJ $\left.1.46 \mathrm{r}\right)$ was used for image processing and analysis of the electrophoretic running of ascending concentration series of BSA (as protein size standard) to quantify the concentration in (ng) of three independent gel repeats. Full data sets showing the quantification counts were supplement separately. Also, Full-length gels are presented in Supplementary Fig. (3a, b). The data was normalized to the protein band running approximately at $300 \mathrm{kDa}$ as shown in Suppl. Fig. 3a

results were reflected as an increase in cytoskeleton protein, growth of lateral roots, and root total area $[19,73]$. Detected IAA higher rate in coriander treated plants with HA supported the latter notion. HA might lead to higher rates of $\mathrm{K}+$ ions uptake and therefore a corresponding increase in chlorophyll fluorescence [67]. Hereby, it might be suggested that HA has improved plant tolerance to abiotic stress and promoted growth by increasing auxins, gibberellins and decreasing ABA (the present data), enhancing nutrient uptakes, photosynthesis, and by reduction of water loss [21, 84]. In addition, stimulation effect of low doses of gamma rays was evidenced by the promotion of various cellular processes, induction the biosynthesis of phytohormones or nucleic acid, accelerated cell proliferation and enzymatic activity, stress resistance, and crop yield $[48,78]$.

The results obviously have shown that pre-sowing coriander seeds in HA was the most effective treatment in mitigation the adverse effect of chilling on seeds yield of coriander plant (Table 4). This result agreed with an earlier study [11]. Improvement of yield and yield components by HA may be attributed to increasing of nutrients uptake, especially nitrogen content, phosphorus and hormone-like effect of HA, or by maintained photosynthetic tissues and leaf chlorophyll increase [74]. Also, the stimulatory effect of endogenous hormones on the cell division and/or enlargement by applied HA was reported by maintaining IAA level, decreasing IAA oxidase 
activity, and promoting metabolic activities which accelerate crops growth and yield [42]. In addition, gamma irradiation has induced improvement of seed yield in the chilling of coriander plants. Similar results were obtained for sunflower [2], Ammi visnage L. [24], and soybean [72]. This could be ascribed to growth stimulation by changing the hormonal signaling network, or by increasing antioxidative capacity of the cell to easily overcome daily stress [47], or by promoting the enzymatic activation resulting in stimulation of cell division rate, which affects not only in germination but also vegetative growth and flowering. In the same context, previous studies have concluded that plant and grain nutritional quality were enhanced by irradiation due to its promoting effect on plant water status by controlling photosynthetic rate, transpiration, and stomatal conductance [90].

\section{HA is the key player in promotion of endogenous phytohormones under chilling stress}

Chilling stress caused a decrease in both IAA and $\mathrm{GA}_{3}$ contents in coriander leaves (Table 5). This may be due to the influence of chilling stress on hormonal balance that affects plant growth and development. Hereby, it could be speculated that the reduction in plant growth under stress conditions could be an outcome of an altered hormonal balance [70]. On the other hand, the amount of ABA detected in coriander leaves increased in response to chilling stress. Abscisic acid accumulated in response to different environmental stresses such as salinity, cold and drought [39]. ABA regulates important cellular processes such as stomatal closure by guard cells, mediated by solute efflux, and regulates expression of many genes that may function in tolerance against chilling stress [39]. On the other hand, pre-soaking coriander seeds in silicate, HA, and irradiation with gamma rays induced higher contents of growth promoting substances (IAA and $\mathrm{GA}_{3}$ ) and lowered ABA level. The most effective treatment that increased (IAA and $\mathrm{GA}_{3}$ ) to alleviate chilling stress was HA (Table 5). In this respect, latter findings agreed with Abdel-Mawgoud et al. [1] who has demonstrated that HA treatment was the causal agent of increased auxins, cytokinins, and $\mathrm{GA}_{3}$ contents in tomato. In the same context, growth promoter (IAA) increased in wheat grown under newly reclaimed soil supplemented with HA [23]. HA might be considered as growth regulator that adjusts hormonal levels, stimulates plant growth, and induces stress tolerance [21]. To a lesser extent, low dose of $\gamma$-rays was found to increase Kinetin and $\mathrm{GA}_{3}$ hormones of Eruca vesicaria $\mathrm{L}$. through triggering changes in hormonal signal network followed by stimulation of growth [71]. It might be concluded that improvement of coriander tolerance to chilling stress was achieved to a higher extent in response to applied HA treatment, followed by silicate. This depended on their role in decreasing IAA oxidase activity, synthesizing adequate level of endogenous phytohormones, promoting metabolic activity, and consequently accelerating plant growth.

\section{Enhancement of photosynthetic pigments by HA in coriander plants with alleviated stress}

The deleterious effect of chilling stress on photosynthetic pigments of coriander leaves was shown through decreasing chl a, chl b, and subsequently the total chlorophylls (Table 6). This result was consistent with earlier experiments conducted on Phaseolus spp. grown at low temperature $\left(10^{\circ} \mathrm{C}\right)$ [97]. The marked reduction in photosynthetic pigments in chilling-stressed coriander leaves might be ascribed to the mechanical forces generated by formation of extracellular ice crystals, cellular dehydration, and increase concentration of intracellular salts [55]. Latter mechanical forces not only resulted in membrane damage and membrane structure alteration but also affected photosynthetic electron transport, $\mathrm{CO}_{2}$ fixation, RubisCO activity, and stomatal conductance $[61,62]$. Application of silicate, HA, and gamma radiation on chilling-stressed plants could alleviate the adverse effect of chilling by increasing $\mathrm{Chl} a, \mathrm{Chl} \mathrm{b}$, and the total chlorophylls levels (Table 5). These results were in harmony with those of Zhu et al. [103], Sivanesan et al. [91], and Habibi [29]. This may be attributed to silicon whose application increased the levels of chl a and $\mathrm{chl} \mathrm{b}$, which in turn indicates synthesis of new pigments and maintenance of previously existing chl a and chl b. However, HA was the most effective treatment in mitigating chilling stress by increasing $\mathrm{Chl}$ a, $\mathrm{Chl} \mathrm{b}$, and consequently total chlorophylls. This may be ascribed to the role of HA as an important biostimulant capable of promoting hormonal activity, producing antioxidants, and reducing free radicals in plants. It has improved root vitality, increased nutrient uptake, stimulated chlorophyll synthesis and/or delayed chlorophyll degradation [57]. Taken together from the presented results, HA treatment restored and maintained the hormonal balance in chilling-stressed coriander to the same level found in the control plants. This balance was triggered by declining ABA levels which mediated root growth enhancement, maintained photosynthetic pigments, and carbohydrates metabolism [63, 70].

\section{Enrichment of carbohydrate content by HA treatment}

In the present investigation, soluble sugars were increased in leaves of the chilling-stressed coriander plant, while polysaccharides and total carbohydrate contents (Table 6) were decreased as compared to the control plant agreeing with the previous investigation of Azymi et al. [12]. The accumulation of total soluble sugars was 
reported as a fundamental component in chilling tolerance in many plant species in response to chilling stress. Soluble sugars might act as compatible solutes under chilling stress [12]. It was suggested that soluble sugars play crucial roles in osmotic adjustment, protection of specific macromolecules, and stabilization of membrane structures [13]. Soluble sugars are thought to interact with phospholipids polar head groups in membranes and to prevent membrane fusion [13]. In addition, sucrose and other sugars play a central role as signaling molecules that regulate the physiology, metabolism and development of plants [8]. The reduction in polysaccharides and total carbohydrates of leaves of chilling coriander plants were correlated with arrested growth rate and decrease in leaf photosynthetic pigments (Table S1; Fig. 4). Specifically, upon HA application, an ameliorative impact in growth, metabolism, and expression of Toc and RuBisCO complexes was triggered (Fig. 4). It might be concluded that cold stress might inhibit the photosynthetic activity and/or increase partial utilization of carbohydrates into the soluble sugars and metabolic products [8]. On the other hand, pre-soaking the seed of coriander plants in silicate, HA, or exposed to gamma radiation induced significant increases in soluble sugar, polysaccharides, and total carbohydrates (Table 6). These effects were much more pronounced by HA alone or in combination with chilling treatment. Similar result concerning the effect of low dose of gamma radiation ( $20 \mathrm{~Gy}$ ) on increasing the carbohydrate contents were reported on onion and potatoe [75] as well as Lupine [46]. HA was found to cause the accumulation of soluble sugars concomitantly with the increase in polysaccharides content and total carbohydrates in wheat plants grown in newly reclaimed soil [14]. Also, silicon has promoted photosynthetic pigments and hence total carbohydrates were increased. It could be concluded that silicate, HA, and gamma radiation alone or in combination with chilling stress have played prominent role in alleviating the water dehydration status caused by chilling stress in coriander plant either via osmotic adjustment by increasing soluble sugars or by stabilizing the chloroplast membrane and enhancing the photosynthetic rate resulting in increased content of carbohydrate biosynthesis.

\section{Antioxidant compounds}

Synthesis of compatible solutes de novo like osmoprotectants, sugars, amino acids, carotenoids, flavonoids, phenols, and polyphenols is regarded as adaptive plant mechanism against osmotic and oxidative stress [9]. The presented study has investigated significant decrease in ascorbic acid content by $46.81 \%$ below the control value caused by chilling stress (Table 7). Furthermore, all individual applied treatments or in combination with chilling stress have induced a significant increase in ascorbic acid content as compared with chilling-stressed plant. The most effective treatment alleviating the impact of chilling stress was HA (Table 7). These results are in harmony with those of Pokluda et al. [79] who reported significant increase in ascorbic acid, total phenolic concentration, and total antioxidant activity in chilled coriander downstream of biostimulants application. On the same context, reduction in carotenoids content was concomitant with significant increase in ABA level in stressed coriander leaves below the control. This might be speculated as an adaptive mechanism to stress. ABA

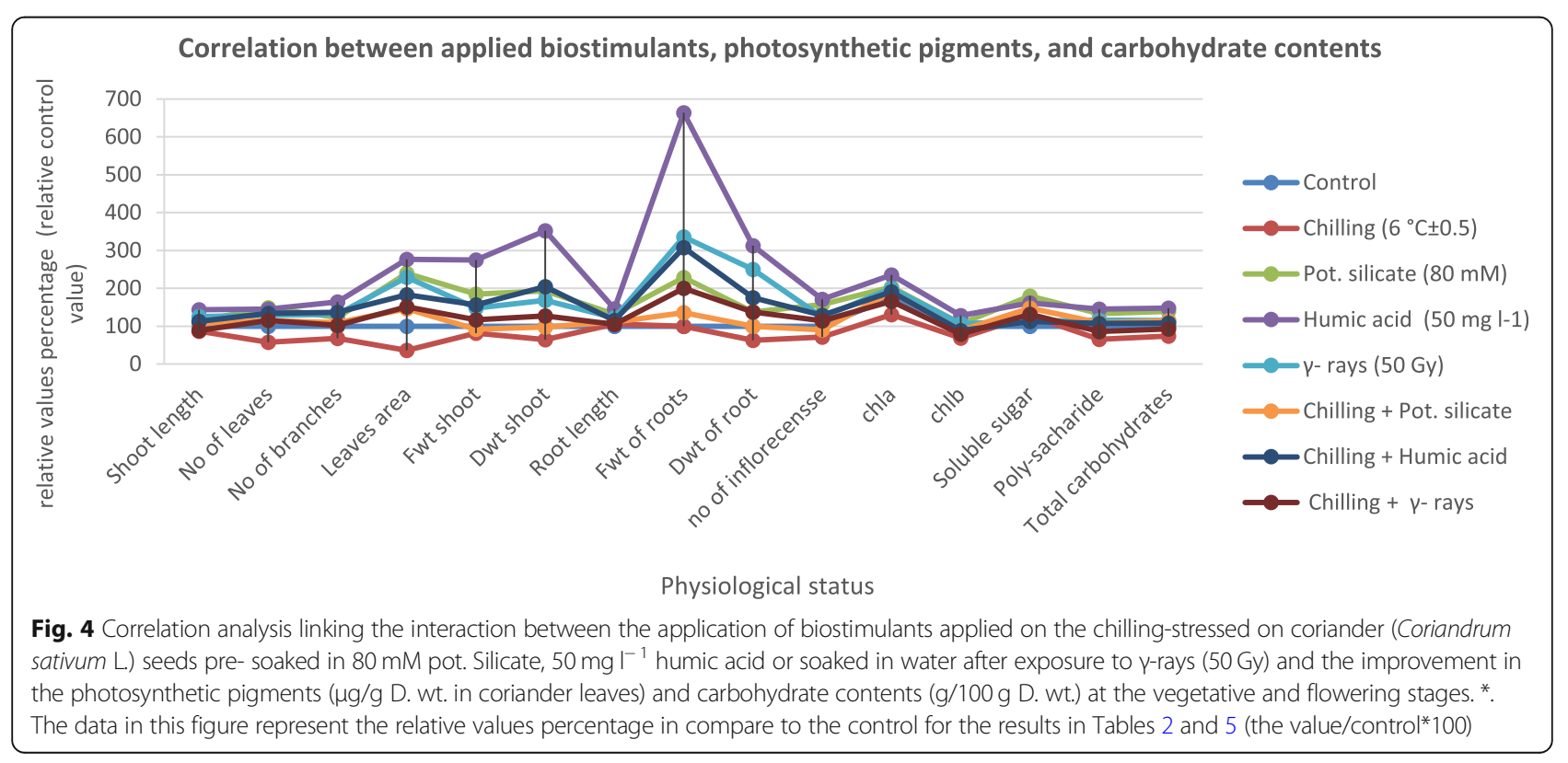


biosynthesis from $\mathrm{C}_{40}$ carotenoids was assured to enable plants to cope with unfavorable condition [33, 104]. Notably, a marked increase in carotenoids content, downstream silicate and HA treatments, was most likely attributed to their antioxidant efficacy in trapping free radical and quenching singlet oxygen [81]. Latter results agreed with that of Habibi [29] who reported that silicon increases synthesis of protective pigment such as carotenoids and anthocyanin in chilling-stressed grapes. The investigated increase of phenols and flavonoids in the presented study, either upon chilling stress or after alleviation using silicate or HA treatments, was also reported by Rivero et al. [82] and then was attributed by Pokluda et al. [79]. The increase in proline content in chilling-stressed coriander leaves was higher than the control values. This might be due to induced synthesis and accumulation of compatible solutes such as proline or due to the inhibition of protein synthesis followed by increased level of free amino acids, especially proline [88]. In the present work, silicate, HA, and $\gamma$ - rays and their interaction with chilling stress have induced a pronounced increase in proline content (Table 7). Latter findings were supported by Ahmad and Haddad [5] who worked on wheat and demonstrated the promoting effect of silicate on proline production under abiotic saline conditions. Moreover, HA and gamma radiation application on chilling-stressed coriander plant were shown to increase proline content. These results were similarly demonstrated on irradiated coriander [53], Pisum sativum L. [77], and wheat [14] plants.

\section{Antioxidant enzymes and lipid peroxidation}

In this study, it was shown that chilling stress has caused a significant increase in CAT, PPO, and POD activities (Table 8 ). These results were in line with previous studies regarding CAT enzyme activity in maize seedlings [27] and other various plant species [50]. Inducing the activity of antioxidant enzymes by chilling stress is most likely regarded as a plant-derived defense mechanism to protect cell membranes, proteins, and metabolic machinery, which would preserve the subcellular structure from damage as a result of cell dehydration [85]. Alleviation of the chilling stress by $\gamma$ - rays, has maintained and/or slightly increased the activity of PPO enzyme. A significant increase in the PPO enzyme activity was found using low doses of $\gamma$-radiation [43]. Furthermore, irradiation by $\gamma$ - rays has increased the PPO and POX capacities in fresh fruits and vegetables [95]. Generally, activities of scavenging enzymes, such as POD, CAT, and SOD increased in various plant species in response to ionizing radiation $[48,101]$, especially the potential activity of POD to remove toxic $\mathrm{H}_{2} \mathrm{O}_{2}$. In the same context, silicon alleviates abiotic stress by enhancing the production of antioxidant enzymes involved in detoxifying free radicals [105]. It also increases their activities which in turn protect plants against ROS generation and lipid peroxidation [30]. The hindrance effect of induced activities of antioxidant enzymes to protect the cells from lipid peroxidation, caused by chilling stress, was evidenced by the reduction of MDA accumulation by all applied treatments. Latter investigation agreed with elsewhere previous studies [29, 64, 72, 85, 102] especially by using HA and silicate as stress alleviation elements.

\section{Significant expression of RuBisCO $\mathrm{LS}_{\mathrm{LS}}$ and toc complex subunits in chilled alleviated coriander plants}

Extracted TCPs were fractionated by SDS-PAGE technique. By achieving high-quality protein profiles, it was important to study and analyze the ameliorative effect of silicate, HA, and gamma irradiation on expressed TCPs generally and $\mathrm{RuBisCO} \mathrm{C}_{\mathrm{LS}}$ expressed protein specifically. High variation in $\mathrm{RuBisCO}_{\mathrm{LS}}$ expression level was revealed by chilling stress (Fig. 1a). Accumulation of $\mathrm{RuBisCO} \mathrm{CS}_{\mathrm{LS}}$ protein product, containing the active site, was demonstrated upon HA treatment [93]. Toc and RuBisCO enzyme complexes were detected at the same molecular weight demonstrated by Ladig et al. [51]. The complex activity was judged by the assembled RuBisCO complex in the cell. The biosynthesis/degradation rate of the RuBisCO two subunits controlled by gene expression is significantly affected by unfavorable abiotic conditions [49]. However, continuous significant accumulation of RuBisCO $C_{L S}$ may have a negative impact on the efficiency and the assembly of RuBisCO complex. Induced changes in the protein profiles of chilling stressed and alleviated samples by HA occurred within a narrow range (45-80 $\mathrm{kDa}$ ) of polypeptides and were recorded in this study (Fig. S1a, b). On the same context, 25 protein spots were differentially and up-regulated in response to low temperature $\left(4{ }^{\circ} \mathrm{C}\right)$ during imbibition in a known chilling-resistant soybean cultivar Z22 [20]. It had been found that optimum temperature for photosynthesis is $20{ }^{\circ} \mathrm{C}$ in barley [94]. Temperature stress has a deleterious effect on the photosynthesis apparatus [83]. In this context, the protein expression of the chloroplast coupling factor (CF1) was negatively affected by the chilling stress [45]. By grouping control and HA alleviated chillingstressed plants together (Fig. 2), the cluster analysis has reflected the ability of HA treatment to alleviate the deleterious effect of chilling stress on the coriander plant

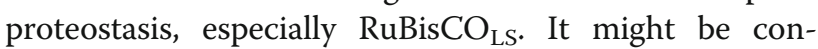
cluded that chilling stress affects the photosynthesis process by disruption of RuBisCO complex assembly inside the chloroplast via down regulating the production of Toc machinery subunits (Toc34 and Toc75) and HSP70 chaperone. Latter impact would limit and restrict RubisCO import and assembly into chloroplast [41]. 
Taken together, it might be concluded that applied growth stimulators in this study, especially HA followed by silicate, have enhanced the antioxidative defense system for limiting the oxidative damage for coriander plants under chilling stress by scavenging excessive ROS through inducing non-enzymatic antioxidant compounds (ascorbic acid, carotenoids, total phenolic, flavonoids, and proline) as well as antioxidant defense enzymes (CAT, POD, and PPO). Besides that, molecular diagnosis of the catalytic effect of biomarkers to reduce the chilling stress at the level of TCPs was assigned and evidenced the restoration and maintenance of RuBisCO $\mathrm{LS}_{\text {. Consequently, achieved }}$ improvements of growth parameters and yield components have reflected previous demonstrations. Hereby, presented results may reflect new insights and broaden our understanding about tolerance mechanism(s) against chilling stress in order to produce winter resistant crops of highly important economic importance like the coriander plant. This study has investigated the potential positioning of physiological, biochemical, and molecular analyses to evaluate and judge the effect of temperature stress fluctuations on the coriander crop in Egypt.

\section{Conclusions}

Acclimation to chilling stress was reinforced in the coriander plant by priming of coriander seeds in potassium silicate $(80 \mathrm{mM})$, humic acid $\left(50 \mathrm{mg} . \mathrm{l}^{1}\right)$ or priming in water after being exposed to gamma rays (50 Gy) and their combination with chilling stress. Alleviated chilling stress was characterized in coriander by improved plant growth and decreased ABA level. Photosynthetic pigments and carbohydrates content (c.a. soluble sugars) were positively promoted concomitantly with polysaccharides and total carbohydrates after alleviation of chilling stress using applied growth stimulators. Moreover, investigated antioxidants compounds and enzymes have undergone either induction or significant increase upon pre- and alleviation treatments. Besides that, induction the accumulation of large subunit of RuBisCO enzyme was also reported as a sign for restoration and maintenance of cellular protein homeostasis. Therefore, it could be suggested that the effectiveness of biostimulators used in this study (especially HA) and their potential stimulatory effect has induced stress tolerance in cultivated coriander under low temperature. The biostimulators applied in the presented study most likely triggered a pronounced step to enhance acclimation and tolerance of coriander plant to chilling stress by safe methods, thus improving and stimulating bioactive hormones, pigments, and healthy components.

\section{Methods}

\section{Plant material and applied treatments}

Coriander (Coriandrum sativum L.) seeds used in this study was assessed by Agricultural Research Center (ARC), Ministry of Agriculture, Giza, Egypt, purchased from seeds suppliers' in Egyptian local market by Abd Elhady Gayar Company, Cairo, Egypt, and named by "Baladi variety". The HA used in this study is produced and purchased from Misr International Company for Agricultural and Industrial Development, Cairo, Egypt. This product is registered and accredited under the name of "HUMO" with No. 7050, Egyptian Ministry of Agriculture, Cairo, Egypt. The prementioned HA product was approved from Agriculture Research Center (ARC), Giza, Egypt. Potassium silicate (99\% degree of purity) was purchased from Sigma-Aldrich Company (Cat. No. 792640). Pilot experiments and basic aspects of the optimization process were carried out with a wide range of potassium silicate or humic acid concentrations (like sub-optimum, optimum, and supra-optimum concentrations). To detect the optimum concentration of $\mathrm{HA}$, various ascending concentration were applied; 5,10 , $25,50,75$, and $100 \mathrm{mg} \cdot \mathrm{l}^{-1}$. The best concentration was $50 \mathrm{mg} . \mathrm{l}^{-1}$. In case of potassium silicate, a series of concentrations; 10, 20, 40, 80, and $160 \mathrm{mM}$ were used. It was found that $80 \mathrm{mM}$ is the optimum concentration. The judgement of the results' quality in the stage of executing the pilot experiments was based on the highest records of growth parameters and yield components. Then, these experimental results were obtained and provided us with a solid basis to which optimum concentration should be selected. The used water source, named as "tap water" in this study, met the standard requirements of WHO (World Health Organization, Geneva 2008). The needed details of the water analysis were accompanied as a supplementary data set. Seed priming was performed by tap water using solutions of potassium silicate $(80 \mathrm{mM})$ or humic acid $\left(50 \mathrm{mg} . \mathrm{l}^{-1}\right)$ prior to seeds chilling $\left(6.0 \pm 0.5^{\circ} \mathrm{C}\right)$ or non-chilling $\left(20.0 \pm 2.0^{\circ} \mathrm{C}\right)$ conditions for $16 \mathrm{~h}$ in water. Similarly, coriander dry seeds were irradiated using gamma rays ( $50 \mathrm{~Gy}$ ) prior to rinsing in non-chilled or chilled water for $16 \mathrm{~h}$. The irradiation experiment for chilled and non-chilled seeds was carried out in National Center for Radiation Research and Technology (NCRRT), Atomic Energy Authority, Cairo, Egypt using Cesium-137 with a dose rate 0.758 $\mathrm{rad} / \mathrm{sec}$. The experiment was carried out during two successive seasons; a short description of experimental protocol is presented and listed in Table 1.

Soaked seeds were washed thoroughly with distilled water, then sown in field plastic pots (L .W .D $=50 \times$ $50 \times 80 \mathrm{~cm})$ containing $15 \mathrm{Kg}$ clay: sandy soil $(2: 1 \mathrm{w} / \mathrm{w})$, ten seeds/pot, and 10 pots for each treatment. The number of pots were counted putting into consideration that 
sample collection was planned to be performed at different growth and developmental stages. Pots were irrigated by tap water to keep $80 \%$ water holding capacity. Plants of the vegetative stage were harvested at day 75 from the sowing date, while, the plants of the flowering stage were harvested after 105 days. Yield components were harvested after 135 day from the sowing date. Throughout this study, three biological and/or three technical replicates were used to measure either growth/ yield parameters or to perform chemical and molecular analyses. Representative samples of ten plants (one pot; counted as one biological replicate) were taken from each treatment at (vegetative stage and flowering stage) to measure the growth parameters; plant height, root length, number of branches /plant, number of leaves/ plant, area of leaves/plant, and fresh and dry weights of shoot and root/ plant. Yield components parameters (number and weight of seeds/ plant as well as seed index) were recorded for each treatment. Chemical analyses were carried out in coriander leaves at flowering stage. The experiments were repeated at the next season and the mean values of growth parameters and yield components were recorded. The experiment design was completely randomized.

\section{Extraction, separation and estimation of growth regulating substances}

The method of extraction was identical to that adopted by Shindy and Smith [87] and described by Hassanein et al. [34]. Determination and identification of acidic hormones (IAA, GA3, and ABA) were performed as described by Kelen et al. [44]. The plant tissues (five grams of each sample out of the three independent used technical replicates) were collected and ground in 80\% methanol. The macerated tissues were transferred to a flask with fresh methanol and the volume was adjusted to $20 \mathrm{ml}$ of methanol for each $\mathrm{g}$ fresh weight of sample. The tissues were extracted for $24 \mathrm{~h}$ at $0{ }^{\circ} \mathrm{C}$ and then was vacuum filtrated through Whatman filter paper (No. 42). The residues were returned to flask with fresh volume of methanol and stirred for $30 \mathrm{~min}$ with magnetic stirrer and then filtrated again. The procedure was repeated once more and combined extract ions were evaporated to the aqueous phase in a rotary flash evaporator. The aqueous phase $(10-30 \mathrm{ml})$ was adjusted to $\mathrm{pH} 8.6$ with $1 \%(\mathrm{w} / \mathrm{v}) \mathrm{NaOH}$ and partitioned three times with equal volumes of ethyl acetate. The combined ethyl acetate fraction was evaporated to dryness and held for further purification. The aqueous phase was adjusted to $\mathrm{pH} 2.8$ with $1 \% \mathrm{HCl}(\mathrm{v} / \mathrm{v})$ and re- partitioned three times with equal volume of ethyl acetate. The remaining aqueous phase was discarded, and the combined acidic ethyl acetate phase was reduced to $5 \mathrm{ml}$ (fraction I) to be used for gas chromatography (GC) determination of acidic hormones such as IAA, ABA and $\mathrm{GA}_{3}$. To estimate the amounts of acidic hormones (fraction I) by HPLC isocratic UV analyzer, reverse phase $\mathrm{C} 18$ column (RO-C18 $\mu$ Bondapak, WATERS corporation, MA, USA) was detected. The column used included octadecylsilane (ODS) ultrasphere particle $(5 \mu \mathrm{m})$, the mobile phases used were acetonitrile-water (26:74 v/v), PH 4.00; Flow rare: $0.8 \mathrm{ml} /$ min, detection by UV at $208 \mathrm{~nm}$, the standard solution of the individual acid was prepared in mobile phase and chromatographed. The retention times of peaks of authentic samples were used in identification and characterization of peaks of samples under investigation. Peak identification was performed by comparing the relative retention time of each peak with those of IAA, $\mathrm{GA}_{3}$, and ABA standard. Peak area was measured by triangulation and relative properties of the individual component were therefore obtained at various retention times of samples.

\section{Estimation of photosynthetic pigments}

The photosynthetic pigments; chlorophyll a (chl a), chlorophyll b (chl b), and carotenoids were determined by Metzner et al. [69]. Briefly, fresh weight of leaves $(0.5$ g) was homogenized in $85 \%$ aqueous acetone for $5 \mathrm{~min}$. The homogenate was centrifuged, and the supernatant was made up to volume with $85 \%$ aqueous acetone. The extinction was measured against a blank of pure $85 \%$ aqueous acetone at 3 wave lengths of $452.5,644$, and $663 \mathrm{~nm}$ using Spectropolarimeter DC Tiny 25III Model TUDC12B4. The photosynthetic pigments were determined in $\mu \mathrm{g} / \mathrm{ml}$ using the following equations: Chlorophyll $a=10.3$ E663-0.918 E644, Chlorophyll $b=19.7$ E644-3.87 E663, and Carotenoids = 4.2 E425.5 - (0.026 chlorophyll $a+0.426$ chlorophyll $b$ ). Finally, the pigment contents were expressed in $\mu \mathrm{g} \cdot \mathrm{g}^{-1}$ of leaves dry weight.

\section{Estimation of carbohydrates}

For soluble sugars and polysaccharides determination, plant material (one gram of fresh tissue) was oven-dried at $80{ }^{\circ} \mathrm{C}$ to constant weight and then ground to a fine powder using local domestic blender. For extraction and estimation of soluble sugars, $25 \mathrm{mg}$ of dried tissues was homogenized using $80 \%$ ethanol, and then kept in boiling water bath with continuous shaking for $15 \mathrm{~min}$. After cooling, the extract was filtrated, and the filtrate was oven dried at $60^{\circ} \mathrm{C}$ then dissolved in $2 \mathrm{ml}$ of water to be ready for determination of soluble sugars [40]. The anthrone sulphuric acid method carried out by Whistler et al. [100] was used for determination of soluble sugars. Polysaccharides were extracted and estimated using the dry residue left after extraction of soluble carbohydrate. A known weight of dried material $(100 \mathrm{mg})$ was added to $10 \mathrm{ml} 1.5 \mathrm{~N}$ sulfuric acid in sugar tubes with air reflux at $100{ }^{\circ} \mathrm{C}$ in a water bath for $6 \mathrm{~h}$. Then, the hydrolysate 
was neutralized by $2.5 \mathrm{~N} \mathrm{NaOH}$ using phenol red as indicator. The latter neutralized solution was used for polysaccharide determination by method of anthrone sulphuric acid reagent [37, 100]. A calibration curve using pure glucose was made, from which the data were calculated as mg/g dry weight. Finally, total carbohydrates content was expressed as the summation of soluble sugars plus polysaccharides amounts in each sample.

\section{Extraction and estimation of antioxidants compounds}

In this study, the antioxidants defense compounds (ascorbic acid, total flavonoids, phenolic compounds, and proline content) were determined. Ascorbic acid was determined in $\mathrm{mg} / 100 \mathrm{~g}$ fresh leaves by 2,6 dichlorophenol indophenol for titration according to Zvaigzne et al. [106]. Briefly, ten grams of leaves were accurately weighed and ground using mortar and pestle with an additional of $20 \mathrm{ml}$ of $3 \%$ metaphosphoric acid- acetic acid solution. The mixture was further ground and strained through muslin and the extract was made up to $100 \mathrm{ml}$ with the metaphosphoric-acetic acid mixture. Five $\mathrm{ml}$ of the metaphosphoric acid-acetic acid solution was pipetted into three of the $50 \mathrm{ml}$ Erlenmeyer flask followed by $2 \mathrm{ml}$ of the samples extract. The samples were titrated separately with the indophenol dye solution until a light rose pink persisted for $5 \mathrm{~s}$. The amount of dye used in the titration were determined and used in the calculation of vitamin $\mathrm{C}$ content. Total flavonoids contents were determined by the aluminum chloride colorimetric assay according to Marinova et al. [66]. Each ethanolic extract $(1.0 \mathrm{ml})$ or standard solution of quercetrin was added to $10 \mathrm{ml}$ volumetric flask containing $4.0 \mathrm{ml}$ distilled water. To the flask $0.3 \mathrm{ml}$ of $5 \%$ $\mathrm{NaNO}_{2}$ was added. After $5 \mathrm{~min}, 0.3 \mathrm{ml}$ of $10 \% \mathrm{AlCl}_{3}$ was added and after $6 \mathrm{~min}, 2.0 \mathrm{ml} 1 \mathrm{M} \mathrm{NaOH}$ was added and the total volume was made up to $10 \mathrm{ml}$ with distilled $\mathrm{H}_{2} \mathrm{O}$. The solution was mixed, and the absorbance was measured against the blank at $510 \mathrm{~nm}$. Finally, total flavonoids were expressed as mg quercetin equivalent per $100 \mathrm{~g}$ of dry weight. Moreover, phenolic compounds were estimated according to Malik and Singh [65] in which phenols could react with phosphormolbdic acid in Folin-Ciocalteau reagent in alkaline medium and produce blue colored complex (molybdenum blue). The absorbance was measured using Milton Roy Spectronic 601 Spectrophotometer at $650 \mathrm{~nm}$. The concentration of phenolic compounds per $100 \mathrm{~g}$ leaves (fresh weight) was calculated from gallic acid standard curve. The values were then calculated as $\left(\mathrm{mg} 100 \mathrm{~g}^{-1}\right)$ dry weight. Free proline was determined according to the method of Bates et al. [15]. This method was based on the reaction between proline and acid ninhydrin reagent. Acid ninhydrin reagent was prepared by warming $1.25 \mathrm{~g}$ ninhydrin in $30 \mathrm{ml}$ glacial acetic acid and $20 \mathrm{ml} 6 \mathrm{M}$ phosphoric acid with agitation until dissolved; kept cool and stored at $4{ }^{\circ} \mathrm{C}$. The reagent remains stable for $24 \mathrm{~h}$. Approximately $0.1 \mathrm{~g}$ of macerated dried tissue was homogenized in $10 \mathrm{ml}$ of $3 \%$ aqueous sulfosalicylic acid, and then filtered through filter paper Whatman No. 2 . Two $\mathrm{ml}$ of the filtrate were mixed with $2 \mathrm{ml}$ glacial acetic acid and $2 \mathrm{ml}$ of the acid ninhydrin reagent in a test tube and heated for $1 \mathrm{~h}$ at $100^{\circ} \mathrm{C}$. The reaction mixture was extracted with $4 \mathrm{ml}$ toluene, mixed vigorously in a test tube for 15-20 s. The chromophore containing toluene was aspired from the aqueous phase and warmed to room temperature. The absorbance was read at $520 \mathrm{~nm}$ using toluene as a blank. The proline concentration was determined using stander curve and calculated on a dry matter basis.

\section{Extraction and measurements of antioxidants enzymes}

The antioxidants enzymes (catalase (CAT), peroxidase (POD), and polyphenol oxidase (PPO)) were extracted from frozen ground leaves $(0.5 \mathrm{~g})$ using cold mortar and pestle and homogenized with cold sodium phosphate buffer $(100 \mathrm{mM}, \mathrm{pH}=7)$ containing $1 \%(\mathrm{w} / \mathrm{v})$ polyvinylpyrrolidone (PVP) and $0.1 \mathrm{mM}$ EDTA. The extraction ratio was $4 \mathrm{ml}$ extraction buffer for each one gram of plant tissues. The homogenate was centrifuged at 10 , $000 \mathrm{~g}$ at $4{ }^{\circ} \mathrm{C}$ for $15 \mathrm{~min}$. The supernatant was used for to measure CAT, POD, and PPO activities. Also, protein concentration was quantified in the crude extract by Lowry et al. [58] using bovine serum albumin as a standard. The activity of CAT (EC 1.11.1.6) was determined according to Aebi [3]. Enzyme extract $(100 \mu \mathrm{l})$ was added to $2.9 \mathrm{ml}$ of a reaction mixture containing $20 \mathrm{mM}$ $\mathrm{H}_{2} \mathrm{O}_{2}$ and $50 \mathrm{mM}$ sodium phosphate buffer ( $\mathrm{pH} 7.0$ ). The activity of CAT was measured by monitoring the reduction in the absorbance at $240 \mathrm{~nm}$ as a result of $\mathrm{H}_{2} \mathrm{O}_{2}$ consumption. The amount of consumed $\mathrm{H}_{2} \mathrm{O}_{2}$ was calculated by using a molar extinction coefficient of 0.04 $\mathrm{cm}^{2} \mu \mathrm{mol}^{-1}$. One unit of enzyme activity was defined as the decomposition of $1 \mu \mathrm{mol}$ of $\mathrm{H}_{2} \mathrm{O}_{2} / \mathrm{min}$. Catalase activity was expressed as unit $\mathrm{min}^{-1} \mathrm{mg}^{-1}$ protein. Also, POD (EC1.11.1.7) activity was quantified by the method described by Hammerschmidt et al. [31]. The assay mixture $(100 \mathrm{ml})$ contained $10 \mathrm{ml}$ of $1 \%(\mathrm{v} / \mathrm{v})$ guaiacol, $10 \mathrm{ml}$ of $0.3 \% \mathrm{H}_{2} \mathrm{O}_{2}$ and $80 \mathrm{ml}$ of $50 \mathrm{mM}$ phosphate buffer $(\mathrm{pH}=6.6)$. Volume of $100 \mu \mathrm{l}$ of crude enzyme was added to $2.9 \mathrm{ml}$ of the assay mixture to start the reaction. The absorbance was recorded every $30 \mathrm{~s}$ for $3 \mathrm{~min}$ at $470 \mathrm{~nm}$ using spectrophotometer (UV-Vis spectrophotometer UV $9100 \mathrm{~B}, \mathrm{LabTech})$. The rate of change in absorbance per minute was calculated and one unit of enzyme was expressed as $\triangle O D=0.01$. The POD activity was expressed as (unit $\mathrm{min}^{-1} \mathrm{mg}^{-1}$ protein). Moreover, PPO (EC 1.14.18.1) activity was measured according to Oktay 
et al. [76]. The reaction mixture contained $600 \mu \mathrm{l}$ catechol $(0.1 \mathrm{M})$ and $100 \mu$ l enzyme extract was completed to $3.0 \mathrm{ml}$ with $0.1 \mathrm{M}$ phosphate buffer $\mathrm{pH}$ 7. The absorbance was recorded at $420 \mathrm{~nm}$ by spectrophotometer (UV-visible-160A, Shimadzu). One unit of PPO activity was defined as the amount of enzyme that causes an increase in absorbance of $0.001 \mathrm{~min}^{-1} \mathrm{ml}^{-1}$. The enzyme activity was expressed as (unit $\mathrm{min}^{-1} \mathrm{mg}^{-1}$ protein).

\section{Estimation of lipid peroxidation}

The lipid peroxidation in fresh coriander leaves was determined by measuring the amount of Malondialdehyde (MDA) produced by thiobarbituric acid (TBA) reaction as described by Heath and Packer [36]. The leaves $(0.5 \mathrm{~g})$ were homogenized in $5 \mathrm{ml}$ of $0.1 \%(\mathrm{~m} / \mathrm{v})$ TCA. The homogenate was centrifuged (Hettich Zentrifugen Universal $16 \mathrm{R}$ Centrifuge, Hettich Rotor 1612 12X3g, Germany) at 10,000 g for $20 \mathrm{~min}$. To an aliquot (1 ml) of the supernatant, $4 \mathrm{ml}$ of $0.5 \% \mathrm{TBA}$ in $20 \%$ TCA was added. The mixture was heated at $95{ }^{\circ} \mathrm{C}$ water bath for $30 \mathrm{~min}$ and then quickly cooled in an ice bath. After centrifugation at $10,000 \mathrm{~g}$ for $15 \mathrm{~min}$, the absorbance of the supernatant was recorded at 532 and $600 \mathrm{~nm}$. The value for non-specific absorption at $600 \mathrm{~nm}$ was subtracted. The concentration of MDA was calculated by dividing the difference of (A532-A600) by its molar extinction coefficient $\left(155 \mathrm{mM}^{-1} \mathrm{~cm}^{-1}\right)$ and the result was expressed as $\left(\mathrm{nmol} \mathrm{g}^{-1}\right)$ fresh weight.

\section{Extraction of total cellular proteins (TCPs) and chloroplast protein complexes from coriander}

TCPs and chloroplast protein complexes were extracted from coriander leaves at the vegetative stage ( 75 days old) according to Mehta et al. [68] with minor modifications. Briefly, chilling stress-primed coriander leaves were ground in liquid nitrogen to a fine powder using the mortar and pestle. To assure complete homogenous cellular disruption, aliquots $(250 \mathrm{mg}$ ) were subjected to high throughput TissueLyser II equipment (Qiagen, Cay. No. 85300) for three times/30 s each. Immediately, extraction buffer $(100 \mu \mathrm{l})$ of $100 \mathrm{mM}$ Tris-HCl PH 8, 50 mM EDTA, 40\% Glycerol, $4 \% \beta$ mercaptoethanol, 2\% w/v SDS, $0.1 \mathrm{mM}$ phenylmethylsulfonyl fluroide (PMSF), $1 \mathrm{x}$ protease inhibitors cocktail (Roche, Penzberg, Germany), and $0.001 \%$ bromophenol blue dye was added to the ground leaves and mixed until a completely homogeneous lysate is obtained using the mortar and pestle. The tissue lysate was vortexed for three minutes, incubated at $95^{\circ} \mathrm{C}$ for $5 \mathrm{~min}$ (Eppendorf ${ }^{\mathrm{su}}$ Thermomixer ${ }^{\mathrm{ru}}$ ), and finally centrifuged (Hettich MICRO 22 centrifuge, Germany) at high speed for $30 \mathrm{~min}$ at $20.000 \mathrm{xg}$. Subsequently, the supernatant was removed and saved as $25 \mu \mathrm{l}$ aliquots at $-80^{\circ} \mathrm{C}$ freezer for further analysis by SDS-PAGE technique. Detection of protein concentration was performed using protein assay dye reagent (BioRad, cat No. \#5000006). Bradford programmed method (Eppendorf Biophotometer, ver. 1.35, Model \#6131) and calibration memory for protein methods were used to quantify the protein concentration according to Bradford [18].

\section{SDS-/ HDN-PAGE and immunoblotting techniques}

Previously extracted TCPs were subjected to either preparatory and/or analytical one-dimensional 10\% SDSPAGE or gradient $4-12 \%$ HDN-PAGE procedures as previously described [51, 52, 68]. Color-coded prestained protein marker (High-Range SDS-PAGE Standards, GeneON, Ludwigshafen, Germany) was loaded and electrophoretic fractionation was carried out using Bio-Rad Mini-Protean II Cell Gel System at $70 \mathrm{~V}$ in $1 \mathrm{X}$ premade tank buffer (BioRad, \#1610734). Protein extraction procedure for each physiological status (control, chilling-stressed, etc.) was performed from the leaves of 3 biological replicates and 3 technical replicates. Each technical replicate represented one biological replicate. Each biological replicate comprises the collection of leaves of 10 plants. The protein extraction was carried out from each technical replicate independently. Finally extracted proteins from the 3 technical replicates were pooled together. Pooled sample was quantified and equally loaded into $10 \%$ SDS-PAGE consequently after measuring its concentration. Aliquots of pooled sample were kept as $-80^{\circ} \mathrm{C}$ after the short snap for $30 \mathrm{~s}$ in Liquid Nitrogen. After completion of protein migration, the gel was stained, de-stained, and finally placed between two sheets of cellophane membrane for immunoblotting technique and/or for documentation purposes as demonstrated by Ladig et al. [51]. Gel images were captured using Bio-Rad gel documentation system (Gel $\operatorname{Doc}^{\text {tm }}$ EZ system and enabled Image Lab ${ }^{\text {tw }}$ software). Protein concentration was revealed using normalized Bovine serum albumin (BSA) standard curve. The cluster analysis was constructed by the following; Band Scoring \{ $(0)$ for absence and (1) for presence\}, based on SDS-PAGE fractionated protein profile, was performed. The binary matrix was generated using the data as revealed by SDSPAGE. The binary matrix was executed to calculate the genetic similarity matrix coefficient. A distance tree was constructed using the unweighted pair group method with arithmetic mean (UPGMA) using PAST, ver. 4.02 as previously described by Hammer et al. [38]. Blotting onto a PVDF membrane $(0.1 \mu$, Schleicher \& Schull, Germany) in Towbin-buffer (192 mM Glycin, $25 \mathrm{mM}$ Tris/HCl, $\quad \mathrm{pH} 8.3,0,1 \% \quad(\mathrm{w} / \mathrm{v}) \quad$ SDS, and $15 \% \quad(\mathrm{v} / \mathrm{v})$ Methanol) was carried out using Bio-Rad Trans-Blot ${ }^{\circ}$ Semi-Dry electrophoretic cell (Cat. number 170-3940) according to manufacturer's instructions. Phosphate buffered saline (PBS), supplemented with Tween-20, were used for membranes washing steps intervening the primary and secondary antibodies incubation times. 
Monoclonal primary antibodies against AtToc75 and At Toc34 (A. thaliana chloroplast outer membrane proteins with 75 and $34 \mathrm{kDa}$, respectively), eukaryotic HSP70 (eHSP70; intermembrane space chaperone for RuBisCO translocation into chloroplast inner membrane), plant Actin (as a control housekeeping gene), and HRP-conjugated secondary anti-rabbit IgG were used. All primary and secondary antibodies were used at dilutions 1: 10,000 and 1: 25,000, respectively and purchased from Agrisera (Vännäs, SWEDEN). Immunoblotting (western blotting, WB), detection of immobilized specific antigens conjugated to Horseradish Peroxidase (HRP), and visualization of HRP was executed by chemiluminescent (ECL) detection kit (Pierce ${ }^{\mathrm{Tx}}$ ECL Western Blotting Substrate, ThermoFisher SCIENTIFIC, Cat. No. 32106) according to the manufacturer's recommendations. Moreover, by using of ImageJ software (IJ 1.46r) for image processing and analysis of the electrophoretic running of ascending concentration series of Bovine serum albumin (BSA), used as protein size standard, quantification of $\mathrm{RuBisCO}$ large subunit $\left(\mathrm{RuBisCO} \mathrm{LS}_{\mathrm{LS}}\right)$ and Toc (Translocon at outer membrane of chloroplast) complex band were performed.

\section{Statistical analysis}

The experimental procedure for each physiological status (control, stress, etc.) was performed from the leaves of 3 biological replicates and 3 technical replicates. Each technical replicate represented the mean of one biological replicate members. Each biological replicate comprises the collection of plant tissue or leaves of 10 plants (one pot). The mean of the independent technical replicates was calculated, and the mean values were used to calculate \pm SE. The data were statistically analyzed for variance and the values of least significant differences (LSD) at 5\% level were calculated to compare the means of different treatments according to Snedecor and Cochran [92]. Different letters indicate significant variation according to Duncan's multiple rang test to discriminate significance (defined as $P<0.05$ ).

\section{Abbreviations}

RuBisCO: Ribulose-1 5-bisphosphate carboxylase/oxygenase;

RuBisCO 1 s: RuBisCO complex large protein subunit; IAA: Indole Acetic Acid; ABA: Abscisic Acid; HA: Humic Acid; Gy: Gray unit; HPLC: High performance thin layer chromatography; HDN-PAGE: Histidine Deoxycholate Native Polyacrylamide Gel Electrophoresis; CAT: Catalase; POD: peroxidase; PPO: polyphenol oxidase; Toc: Translocon at the outer envelope membrane of chloroplast

\section{Supplementary Information}

The online version contains supplementary material available at https://doi. org/10.1186/s12870-021-03021-6.

Additional file 1: Suppl. Fig. 1. Impact of alleviation treatments on growth parameters of chilling-stressed coriander plants at the flowering stage. Suppl. Fig. 2. Impact of alleviation treatments on TCPs profiles of chilling-stressed $\left(6^{\circ} \mathrm{C} \pm 0.5\right)$ coriander plants at the vegetative stage (75 days old). Protein extraction procedure for each physiological status (control, stress, etc.) was performed from the leaves of 3 biological and 3 technical replicates. Each technical replicate represented one biological replicate. Each biological replicate is composed of the collection of leaves of 10 plants. The latter collected leaves represented one technical replicate. The protein extraction was carried out from each technical replicate independently. Finally extracted proteins from the 3 technical replicates were pooled together. Pooled sample were quantified and equally loaded into 10\% SDS-PAGE consequently after measuring its concentration. Aliquots of pooled sample were kept as $-80^{\circ} \mathrm{C}$ after the short snap for $30 \mathrm{~s}$ in Liquid Nitrogen. Coriander control (Lane 1) seeds and chillingstressed (Lane 2) ones were subjected to pre- soaking in $80 \mathrm{mM}$ Pot. silicate (Lane 3), $50 \mathrm{mg} \mathrm{l}^{-1} \mathrm{HA}$ (Lane 4) or soaked in water after exposed to 50 Gy gamma irradiation (Lane 5). TCPs were then extracted, fractionated on 10\% SDS-PAGE for season 1 (Panel a) and season 2 (Panel b), and finally stained with CoBB stain. The numbers shown on the left-handed side of the figures indicate molecular weight standards in KDa (HighRange SDS-PAGE Standards, GeneON, Ludwigshafen, Germany). Red arrowheads refer to induced upregulated polypeptides detected in "chillin$\mathrm{g}+\mathrm{HA}$ ", but not in "Chilling" and/or other chilling plus alleviation elements. The asterisk refers to approximate molecular weight of RuBis-

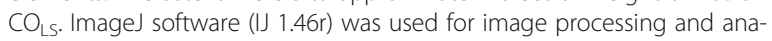
lysis of the electrophoretic running of ascending concentration series of BSA (as protein size standard) to quantify RuBis $\mathrm{CO}_{\mathrm{LS}}$ concentration in $(\mu \mathrm{g})$ downward of every panel. Full-length gels are presented in Supplementary Fig. (2a and b). Black arrowhead refers to the protein band at approximate molecular weight of $180 \mathrm{kDa}$ used for normalization of quantified RuBisCO LS protein expression. Suppl. Fig. 3 Full-length original and unprocessed Immunoblot analysis of the expression of chloroplast marker proteins. TCPs were extracted and fractionated by SDS-PAGE and immunodecorated against a-Toc34, a-Toc75, eHSP70, and actin primary antibody in a dilution of 1:10,000 as demonstrated in [51]. Cropping of the shown blots was performed properly for sake of clarity and focusing the information. Full-length blots are accompanied the manuscript as Supplementary Fig. 3. Protein extraction procedure for each physiological status (control, chilling stressed, etc.) was performed from the leaves of 3 biological replicates and 3 technical replicates. Each technical replicate represented one biological replicate. Each biological replicate comprises the collection of leaves of 10 plants. The protein extraction was carried out from each technical replicate independently. Finally extracted proteins from the 3 technical replicates were pooled together. Pooled sample were quantified, equally loaded into 10\% SDS-PAGE, and blotted onto PVDF membrane as shown in methods section. Consequently, aliquots of pooled sample were kept as $-80^{\circ} \mathrm{C}$ after the short snap for $30 \mathrm{~s}$ in Liquid Nitrogen. Suppl. Fig. 4 Fractionation of chloroplast protein complexes by HDN-PAGE technique profiles of chilling-stressed $\left(6^{\circ} \mathrm{C} \pm 0.5\right)$ coriander plants at the vegetative stage. Panel (a) Coriander control (Lane 2, 7) seeds and chilling-stressed (Lane 3) ones were subjected to pre- soaking in $80 \mathrm{mM}$ Pot. silicate (Lane 5), $50 \mathrm{mg} \mathrm{I}^{-1} \mathrm{HA}$ (Lane 5) or soaked in water after exposed to 50 Gy gamma irradiation (Lane 6). Extracted protein complexes (especially RuBisCO enzyme complex) were then fractionated on $4-12 \%$ gradient native HDN-PAGES, and finally stained with COBB stain. Native molecular weight standards (HMW Native Marker kit, GE Healthcare) (lane 1) was loaded and denoted by numbers left-handed of the figure indicating molecular weight standards in $\mathrm{kDa}$. Image J software (IJ 1.46r) was used for image processing and analysis of the electrophoretic running of ascending concentration series of BSA (as protein size standard) to quantify RuBisCO $\mathrm{LS}_{\mathrm{LS}}$ concentration and Toc complex bands in $(\mu \mathrm{g})$ were depicted downward of the figure. Cropping of the HDN-PAGE shown was performed for sake of clarity and focusing the information. Full-length original HDN-PAGE gel is presented in Supplementary Fig. 4 (Repeat 1, 2). Black arrowhead refers to the protein band at approximate molecular weight of $300 \mathrm{kDa}$ used for normalization of quantified Toc and RuBisCO protein complexes. Original full length HDNPAGEs; Repeat 1 (Panel a) and Repeat 2 (Panel b) were shown without cropping for sake of clarity. Repeat 1 and 2 were executed to manifest the consistency and reproducibility of the given protein complexes. Panel (b) specifically showed also the loading of different concentrations of 
solubilized protein complexes of control sample for optimization and high-resolution purposes.

\section{Additional file 2.}

Additional file 3: Supplementary Table 1. Correlation matrix linking the interaction between the application of biostimulants applied on the chilling-stressed on coriander (Coriandrum sativum L.) seeds pre- soaked in $80 \mathrm{mM}$ pot. Silicate, $50 \mathrm{mg} \mathrm{I}^{-1}$ humic acid or soaked in water after exposure to $\gamma$-rays (50 Gy) and the improvement in both the photosynthetic pigments ( $\mu \mathrm{g} / \mathrm{g} \mathrm{D}$. wt. in coriander leaves) and carbohydrate contents ( $\mathrm{g} /$ $100 \mathrm{~g} \mathrm{D}$. wt.) at the vegetative and flowering stages. *. Correlation is significant at the 0.05 level (2-tailed). ${ }^{* *}$. Correlation is significant at the 0.01 level (2-tailed)

\section{Acknowledgments}

The authors would like to express their gratitude to postgraduate studies and research affairs, Faculty of Science, Ain Shams University, Cairo, Egypt and Department of Natural Products, National Center for radiation Research and Technology, Atomic Energy Authority for the support during out the study support and providing possible research grant to Faculty affiliates to obtain valuable materials and reagents without which this work would not have appeared to light. Also, the authors appreciate the keen collaboration of Department of Natural Prod Res. Dept., National Center for Radiation Research and Technology, Atomic Energy Authority, Cairo, Egypt. The authors thank the efforts of Dr. Reda Salem, researcher at Agricultural Genetic Engineering Research (AGERI), Agricultural Research Center (ARC), Giza, Egypt during the protein analysis by SDS-PAGE technique. The authors are greatly appreciating Dr. Hind Ahmed, lecturer of ecology, Department of Botany, Faculty of Science, Ain Shams University, Cairo, Egypt for her support to validate the data statistically and Prof. Dr. Enrico Schleiff, professor of molecular cell biology of plants, Goethe University, Frankfurt am Main, Germany for his knowledge valorization and Kind providing of all needed support and advices regarding HDN-PAGE and blotting techniques accordingly. The authors are so thankful for Victoria Foley and Prof. Nahila El-Sherif for performing keen English language editing of the manuscript by which the manuscript is highly improved.

\section{Authors' contributions}

$\mathrm{RAH}, \mathrm{OSH}, \mathrm{AFA}$ and $\mathrm{Ml}$ assessed the conceptualization of presented research point. RAH, OSH, AFA, IAF, YEH and MI conceived and designed the experimental methodology. OSH, AFA, IAF, YEH and MI performed the experimental analysis. OSH, AFA, IAF and MI were responsible for data curation. YEH and Ml prepared and wrote the original manuscript draft. RAH, OSH, AFA and MI wrote, reviewed and edited the approved manuscript. RAH and Ml supervised all submission procedures. All authors have read and approved the final manuscript.

\section{Funding}

All gratitude to postgraduate studies and research affairs at Faculty of Science, Ain Shams University and Department of Natural Products, National Center for radiation Research and Technology, Atomic Energy Authority for the support during out the study. However, prementioned institution has no role in conceptualization, methodology, experimental design and analysis, submission of the current manuscript, and finally in funding the publishing charges. Not Applicable funding source.

\section{Availability of data and materials}

All datasets generated and/or analyzed during this study were completely included within the article and its supplementary information.

\section{Declarations}

Ethics approval and consent to participate Not applicable.

\section{Consent for publication}

Not applicable.

\section{Competing interests}

The authors declare that they have no conflict interests in this paper.

\section{Author details}

'Department of Botany, Faculty of Science, Ain Shams University, Cairo 11355, Egypt. ${ }^{2}$ Department of Natural Products, National Center for Radiation Research and Technology, Atomic Energy Authority, P.O. 29, Cairo, Nasr City, Egypt.

Received: 22 June 2020 Accepted: 10 May 2021

Published online: 07 August 2021

\section{References}

1. Abdel-Mawgoud AMR, El-Greadly NHM, Helmy YI, Singer SM. Responses of tomato plants to different rates of humic based fertilizer and NPK fertilization. J App Sci Res. 2007;3(2):169-74.

2. Abo-Hegazi AMT, Al R, Moustafa AK. Heritability and genetic variability of some characters of sunflowers in M3and M4 generation after irradiation. Minufiya J Agric Res. 1988;13:3-5.

3. Aebi H. Methods of enzymatic analysis. In: Bergmeyer HU, editor. Catalase. Weinheim /NewYork, USA: Verlag Chemie/academic press Inc.; 1974. p. 673-80

4. Aghaee A, Moradi F, Zare-Maivan H, Zarinkamar F, Pour Irandoost $H$, Sharifi P. Physiological responses of two rice (Oryza sativa L.) genotypes to chilling stress at seedling stage genotypes to chilling stress at seedling stage. Afr J Biotechnol. 2011;10(39):7617-21.

5. Ahmad ST, Haddad. R Study of Silicon Effects on Antioxidant Enzyme Activities and Osmotic Adjustment of Wheat under Drought Stress. Czech J Genet Plant Breeding. 2011;47(1):17-27. https://doi.org/10.1 7221/92/2010-CJGPB.

6. Akshatha K, Chandrashekar R, Somashekarappa HM, Souframanien J. Effect of gamma irradiation on germination, growth, and biochemical parameters of Terminalia arjuna Roxb. Radiat Prot Environ. 2013;14(1):139-55. https:// doi.org/10.4103/0972-0464.121826.

7. Ali H, Ghori Z, Sheikh S, Gul A. Effects of gamma radiation on crop production. Switzerland, Islamabad: Atta-ur-Rahman School of applied biosciences (ASAB), National University of Sciences and Technology (NUST), Pakistan springer international publishing; 2016. p. 27-78.

8. Arroyo A, Bossi F, Finkelstein RR, Leon P. Three genes that affect sugar sensing (abscisic acid insensitive 4, abscisic acid insensitive 5 and constitute triple response 1) are differentially regulated by glucan in Arabidopsis. Plant Physiol. 2003;133(1):231-42. https://doi.org/10.1104/pp.103.021089.

9. Ashraf M, Harris PGC. Biochemical indicators of salinity tolerance in plant. Plant Sci. 2004;166(1):3-16. https://doi.org/10.1016/j.plantsci.2003.10.024.

10. Ashraf M, Rahmatullah B, Afzal M, Ahmed RR, Mujeeb F, Sarwar A, et al. Alleviation of determinal effect $\mathrm{s}$ of $\mathrm{NaCl}$ by silicon nutrition in salt senestive and salt-tolerance genotype of sugarcane (Saccharum officinarum L.). Plant Soil. 2010;326(1-2):381-91. https://doi.org/10.1007/s11104-009-0019-9.

11. Ayas $\mathrm{H}$, Gulser $\mathrm{F}$. The effects of sulfur and humic acid on yield components and macronutrient contents of spinach (Spinacia Oleracea var. Spinoza). J Biol Sci. 2005;5(6):801-4.

12. Azymi S, Sofalian O, Jahanbakhsh GS, Khomari S. Effect of chilling stress on soluble protein, sugar and proline accumulation in Gossypium hirsutum L. genotypes. Inter J of Agric Crop Sci. 2012;4(12):825-30.

13. Bartels D, Sunkar R. Drought and tolerance in plants. Critic Rev Plant Sci. 2005;24(1):23-58. https://doi.org/10.1080/07352680590910410.

14. Bassuony FM, Hashem HA, Hassanein RA, Baraka DM, Khalil RR. Ameliorative effect of sigmasterol on the productivity of Viciafaba plants grown under salt stress. J Plant Production Mansoura Univ. 2011;2(4):597-615. https://doi. org/10.21608/jpp.2011.85595.

15. Bates LS, Waldern RP, Tear ID. Rapid determination of free proline for water-stress studies. Plant Soil. 1973;39(1):205-7. https://doi.org/10.1007/ BF00018060.

16. Berbara RLL, García AC. Humic substances and plant defense metabolism. In: Ahmad P, Wani MR, editors. Physiological mechanisms and adaptation strategies in plants under changing environment, vol. 1. New York: Springer science+business media; 2014. p. 297-319. https://doi.org/10.1007/978-1-4 614-8591-9_11.

17. Bloom AJ, Zwieniecki MA, Passioura JB, Randall LB, Holbrook NM, Clair DAST. Water relations under root chilling in a sensitive and tolerant tomato species. Plant Cell Environ. 2004;27(8):971-9. https://doi.org/10.1111/j.1365-3 040.2004.01200.x.

18. Bradford MM. A rapid and sensitive method for the quantitation of microgram quantities of protein utilizing the principle of protein-dye 
binding. Anal Biochem. 1976;72(1):248-54. https://doi.org/10.1016/0003-2 697(76)90527-3.

19. Canellas LP, Spaccini R, Piccolo A. Relationships between chemical characteristics and root growth promotion of humic acids isolated from Brazilian oxisols. Soil Sci. 2009;174(11):611-20. https://doi.org/10.1097/SS. 0b013e3181 bf1e03.

20. Cheng LG, Xuan L, Shuyan S, Mengjun H, Javeed J, Xinming Y, et al. Proteomic analysis of soybean [Glycine max (L.) Meer.] seeds during imbibition at chilling temperature. Mol Breed. 2010;26(1):1-17. https://doi. org/10.1007/s11032-009-9371-y.

21. Cimrin KM, Turkmen O, Turan M, Tuncer B. Phosphorus and humic acid application alleviate salinity stress of pepper seedlings. Afr J Biotechnol. 2010;9:5845-51.

22. Desai $\mathrm{AS}$, Rao $\mathrm{S}$. Effect of gamma radiation on germination and physiological aspects of pigeon pea (Cajanus cajan (L.) millsp). Seedlings. Int J Res Appl. 2014;2(6):47-52.

23. El-Bassiouny HSM, Bakry B, Attia AA, Abd-Allah MM (2014) Physiological role of humic Acid and nicotinamide on improving plant growth, yield, and mineral nutrient of wheat (Triticum aestivum) grown under newly reclaimed sandy soil. Agric Sci. 2014;5:687-700.

24. El-Shafie SA, Marzou MM, El-Kholy SA. Physiological influence of pre-sowing gamma irradiation on growth, drug yield and some chemical constituents of Ammi visnage L. plants. Minufia J Agric Res. 1993;18:2565-78.

25. Eneji AE, Inanaga S, Muranaka J, Li P, Hattorri AT, Tsuji W. Effect of calcium silicate on growth and dry matter yield of Chloris gayana and Sorghum sudanense under two soil water regimes. Grass Forage Sci. 2005;60(4):393-8. https://doi.org/10.1111/j.1365-2494.2005.00491.x.

26. Farag IA, Hussein OS, Hassan YE. Improvement of seedling growth celery (Apium groveolence L.) using humic acid, potassium silicate and low gamma irradiation doses. Zagazig J Agric Res. 2014;41(4):737-45.

27. Faroog M, Aziz T, Cheema ZA, Hussain M, Khalid A. Activation of antioxidant system by $\mathrm{KC} 1$ improves the chilling tolerance in hybrid maize. J Agron Crop Sci. 2008;194:438-48.

28. Gumus T. Determination of the changes of antifungal properties of Satureja hortensis, Thymus vulgaris and Thymbra spicata exposed to gamma irradiation. Radiat Phys Chem. 2010;79(1):109-14. https://doi.org/10.1016/..ra dphyschem.2009.07.025.

29. Habibi G. Effects of soil-and foliar -applied silicon on the resistance of grapevine plants to freezing stress. Acta Biologica Szegediensis. 2015;59(2): 109-17.

30. Habibi G, Hagiboland R. Alleviation of drought stress by silicon supplementation in pistachio (Pistacia vera L.) plants. Folia Hort. 2013;25(1): 21-9. https://doi.org/10.2478/fhort-2013-0003.

31. Hammerschmidt R, Nuckles E, Kuc J. Association of enhanced peroxidase activity with induced systemic resistance of cucumber to Colletotrichum lagenarium. Physiol Plant Pathol. 1982;20(1):73-82. https://doi.org/10.1016/ 0048-4059(82)90025-X

32. Hasanuzzaman M, Nahar K, Alam MDM, Roychowdhury R, Fujita M. Physiological, biochemical, and molecular mechanisms of heat stress tolerance in plants. Int J Mol Sci. 2013;14(5):9643-84. https://doi.org/10.33 90/ijms 14059643.

33. Hassan YE (2010) Physiological studies on Ocimum basilicum L. plants as affected by gamma radiation, glycine betaine and salinity stress. M.Sc. Thesis. Faculty of Science, Ain shams Univ., Cairo, Egypt.

34. Hassanein RA, Hassanein AA, Haider A, Hashem HA. Improving salt tolerance of Zea mays L. plants by presoaking their grains in glycine betaine. Aust J of Basic and App Sci. 2009;3(2):928-42

35. Hazekamp A. Evaluating the effects of gamma-irradiation for decontamination of medicinal cannabis. Front Pharmacol. 2016;7(108):1-12.

36. Heath RL, Packer L. Photoperoxidation in isolated chloroplasts. I. Kinetics and stoichiometry of fatty acid peroxidation. Arch Biochem Biophys. 1968; 125(1):189-98. https://doi.org/10.1016/0003-9861(68)90654-1.

37. Hedge JE, Hofreiter BT. Anthrone coluorimetric method. In: Methods in Carbohydrate Chemistry, vol. 1. New York: Academic Press; 1962. p. 380-94.

38. Hammer $\varnothing$, Harper DAT, Ryan PD. Past: paleontological statistics software package for education and data analysis, Palaeontol. Electron. 2001;4:1-9.

39. Himmelbach $A$, Yang $Y$, Grill E. Relay and control of abscisic acid signaling. Curr Opin Plant Bio. 2003;6(5):470-9. https:/doi.org/10.1016/S1369-5266(03)00090-6.

40. Homme PM, Gonalez B, Billard L. Carbohydrate content, fructane and sucroce enzyme activities in roots, stubble and leaves of rye grass (Lolium perenne L.) as affected by source/sink modification after cutting. J Plant Physiol. 1992;140(3):282-91. https://doi.org/10.1016/S0176-1617(11)81080-1.

41. Ibrahim M (2012) First insights into the phosphorylation of Toc34 proteins. Ph.D. Thesis, Department of Biosciences, Goethe University, Frankfurt am Main, Germany, pp 106.

42. Kalaichelvi K, Chinnusamy C, Arul SA. Exploiting the natural Resourse-lignite humic acid in agriculture. Agric Rev. 2006;27:276-83.

43. Kebeish $\mathrm{R}$, Deef HE, El-Bialy N. Effect of gamma radiation on growth, oxidative stress, antioxidant system, and alliin producing gene transcripts in Allium sativum. Inter J Res StudBio sci. 2015;3(3):161-74.

44. Kelen M, Demiralay EC, Sens S, Ozkann G. Separation of abscicic acid, indole-3-acetic acid, gibberellic acid in 99R (Vitis berlandieri x Vitis rupestris) and rose oil (Rosa damascene Mill.) reversed phase liquid chromatography. Turk. J. Chem. 2004;28:603-10.

45. Khalifa N, Ibrahim M, Sakran A, Shehata M, Abdelsattar M. Differential Expression of RuBisCO large subunit and its assembly in intact chloroplasts of Pisum sativum L. treated with $\mathrm{NaCl}$ and jasmonic acid. Egypt J Bot. 2017; 57(3):525-37. https://doi.org/10.21608/EJBO.2017.1050.1092.

46. Khodary SEA, Moussa HR. Influence of gamma radiation and or salinity on some physiological characteristics of lupine plants. Egypt J Biotechnol. 2003; 13:29-36.

47. Kim JH, Baek MH, Chung BY, Wi SG, Kim JS. Alterations in the photosynthetic pigments and antioxidant machineries of red pepper (Capsicum annum L.) seedlings from gamma-irradiated seeds. J Plant Biol. 2004;47(4):314-21. https://doi.org/10.1007/BF03030546.

48. Kim JH, Chung BY, Kim JS, Wi SG. Effects of gamma irradiation on growth, photosynthesis and antioxidative capacity of red pepper (Capsicum annuum L.) plants. J plants Biol. 2005;48(1):47-56. https://doi.org/10.1007/BF03030564.

49. Krapp A, Hofmann B, Schäfer C, Stitt M. Regulation of the expression of rbcS and other photosynthetic genes by carbohydrates: a mechanism for the 'sink regulation' of photosynthesis? Plant J. 1993;3(6):817-28. https://doi. org/10.1111/j.1365-313X.1993.00817.X.

50. Kumar S, Gupta D, Nayyar H. Comparative response of maize and rice genotypes to heat stress: status of oxidative stress and antioxidants. Acta Physiol Plant. 2012;34(1):75-86. https://doi.org/10.1007/s11738-011-0806-9.

51. Ladig R, Sommer MS, Hahn A, Leisegang MS, Papasotiriou DG, Ibrahim M, et al. A high-definition native polyacrylamide gel electrophoresis system for the analysis of membrane complexes. Plant J. 2011;67(1):181-94. https://doi. org/10.1111/j.1365-313X.2011.04577.x.

52. Laemmli UK. Cleavage of structural proteins during the assembly of the head of bacteriophage T4. Nature. 1970;227(5259):680-5. https://doi.org/10.1 038/227680a0.

53. Latif HH, Abdalla MA, Farag S. Radio-stimulation of phytohormons and bioactive components of coriander seedlings. Turk J Biochem. 2011;36(3): 230-6.

54. Leena K, Sharma A, Lodi S. Potential health benefits of coriander (Coriandrum sativum L.): an overview. Int J Pharmaceut Res Development. 2012:4(2):010-20.

55. Levitt J (1980) Responses of plants to environmental stresses. $2^{\text {nd }}$ ed., Vol. 1. Chilling, freezing and high temperatures stresses. New York; London (etc.): Academic press.

56. Liang YC, Zhang WH, Chen Q, Ding RX. Effects of silicon on tonoplast HpATPase and $\mathrm{Hb}$-PPase activity, fatty acid composition and fluidity in roots of salt-stressed barley (Hordeum vulgare L.). Env Exp Bot. 2005;53(1):29-37. https://doi.org/10.1016/j.envexpbot.2004.02.010.

57. Liu C, Cooper RJ (2000) Humic substances influence creeping bent grass growth. Golf Course Manag 49-53.

58. Lowry OH, Rosebrough NJ, Farr AL, Randal RJ. Protein measurement with the Folin phenol reagent. J Biol Chem. 1951;193(1):265-75. https://doi.org/1 $0.1016 / 50021-9258(19) 52451-6$

59. Lütz C. Cell physiology of plants growing in cold environments. Protoplasma. 2010;244(1-4):53-73. https://doi.org/10.1007/s00709-010-0161-5.

60. Ma JF. Role of silicon in enhancing the resistance of plants to biotic and abiotic stresses. Soil Sci Plant Nutr. 2004;50(1):11-8. https://doi.org/10.1080/ 00380768.2004.10408447.

61. Ma JF, Goto S, Tamai K, Ichii M. Role of root hairs and lateral roots in silicon uptake by rice. Plant Physiol. 2001a;127(4):1773-80. https://doi.org/10.1104/ pp.010271.

62. Ma JF, Miyake Y, Takahashi E (2001 b) Silicon beneficial element for crop plants. In: Datnoff LE, Snyder GH, Komdorfer GH (Eds) Silicon Agricultute, Elsvie Science B.V Amsterdam pp17-39. 
63. Mahajan S, Tuteja N. Cold, salinity and drought stresses: an overview. Arch Biochem Biophys. 2005;444(2):139-58. https://doi.org/10.1016/j.abb.2005.10.018.

64. Malhotra CH, Kapoor R, Gnjwala D. Alleviation of a biotic stress and biotic stress in plant by silicon supplementation. Sci Agric. 2016;13(2):59-73.

65. Malik CP, Singh MB. In plant enzymology and histo-enzymology. New Delhi: Kalyani Puplishers; 1980. p. 53.

66. Marinova D, Ribarova F, Atanassova M. Total phenolic and total flavonoids in Bulgarian fruits and vegetables. J Univ Chem Technol Metallurgy. 2005; 40(3):255-60.

67. Marschner H (1995) Mineral nutrition of higher plants, second edition, London 16: 889pp academic press,

68. Mehta RA, Fawcett TW, Porath D, Mattoo AK. Oxidative stress causes rapid membrane translocation and in vivo degradation of ribulose-1, 5bisphosphate carboxylase/oxygenase. J Biol Chem. 1992;267(4):2810-6. https://doi.org/10.1016/S0021-9258(18)45951-0.

69. Metzner H, Raum H, Senger H. Unterschungen Zur Synchno-nisier-Barkeit einze-Iner Pigmenmangel-Mutanten-von. Chlorella Planta. 1965;65(2):186-94. https://doi.org/10.1007/BF00384998.

70. Mora V, Baigorri R, Bacaicoa E, Zamarreno AM, Garcia-Mina JM. The humic acid-induced changes in the root concentration of nitric oxide, IAA and ethylene do not explain the changes in root architecture caused by humic acid in cucumber. Env Exp Bot. 2012;76:42-32.

71. Moussa HR. Gamma irradiation regulation of nitrate level in rocket (Eruca vesicaria subsp. sativa) plants. J New Seeds. 2006;8(1):91-100. https://doi. org/10.1300/J153v08n01_08.

72. Moussa HR. Low dose of gamma irradiation enhanced drought tolerance in soybean. Bulg J Agric Sci. 2011;17(1):63-72.

73. Nardi S, Carletti P, Pizzeghello D, Muscolo, A (2009) Biological activities of humic substances. In: Senesi N, Xing B, Huang PM (eds) Biophysicochemical processes involving natural nonliving organic matter in environmental systems. Wiley Hoboken pp. 305-339.

74. Nardi S, Pizzeghello D, Muscolo A, Vianello A. Physiological effects of humic substances on higher plants. Soil Bio Biochem. 2002;34(11):1527-36. https:// doi.org/10.1016/S0038-0717(02)00174-8.

75. Nouri J, Toofanian F. Extensions of storage of onions and potatoes by gamma irradiation. Pakistan J Boi Sci. 2001;4:1275-8.

76. Oktay M, Kufrevioğlu OI, Kocacaliskan I, Sakiroğlu H. Polyphenol oxidase from Amasya apple. J. Food Sci. 1995;60:495-9.

77. Osman ASH, Rady M. Ameliorative effects of Sulphur and humic acid on the growth, antioxidant levels, and yields of pea (Pisum sativum L.) plants grown in reclaimed saline soil. J Hort Sci \& Biotech. 2012;87(6):626-32. https://doi. org/10.1080/14620316.2012.11512922

78. Pitirmovae MA. Effect of gamma rays and mutagens on barley seeds. Fiziol Res. 1979;6:127-31.

79. Pokluda R, Sękarab A, Jezdinskýa A, Kaliszb A, Neugebauerováa J, Grabowskab A. The physiological status and stress biomarker concentration of Coriandrum sativum L. plants subjected to chilling are modified by biostimulant application. Biol Agric Hort. 2016;32(4):258-68. https://doi.org/1 0.1080/01448765.2016.1172344

80. Rady MM, Osman ASH. Effects of the application of 'cash' on the growth, fruit yield and nutrient status of tomato (Solanum Iycopersicum L.) grown in reclaimed saline soil. J Hort Sci Bio tech. 2011;86:626-30.

81. Reisches DW, Lillard DA, Eitenmiller RR (2002) Antioxidants in: food lipids, 2nd ed. Akoh CC, min DB, Marcel, Dekker NY, USA pp 489-516.

82. Rivero RM, Ruiz J.M, García PC, López-Lefebre LR, Sánchez E, Romero L (2001) Resistance to cold and heat stress: accumulation of phenolic compounds in tomato and watermelon plants. Plant Sci 160 (2): 315-321, DOl: https://doi.org/10.1016/S0168-9452(00)00395-2.

83. Rollins J, Habte E, Templer S, Colby T, Schmidt J, Von Korff M. Leaf proteome alterations in the context of physiological and morphological responses to drought and heat stress in barley (Hordeum vulgare L.). J Exp Bot. 2013;64(11):3201-12. https://doi.org/10.1093/jxb/ert158.

84. Saruhan $V$, Kusvuran A, Babat S. The effect of different humic fertilization on yield and yield components performances of common millet (Panicum miliaceum L.). Sci Res Essays. 2011;6:663-9.

85. Sekmen Esen AHE, Ozgur R, Uzilday B, Tanyolac ZO, Dinc A. The response of the xerophytic plant Gypsophila aucheri to salt and drought stresses: the role of the antioxidant defense system. Turk J Bot. 2012;36:697-706.

86. Sharma P, Sharma N, Deswal R. The molecular biology of the lowtemperature response in plants. Bioessays. 2005;27(10):1048-59. https://doi. org/10.1002/bies.20307.
87. Shindy WW, Smith O. Identification of plant hormones from cotton ovules. Plant Physiol. 1975;55(3):550-4. https://doi.org/10.1104/pp.55.3.550.

88. Shinozaki K, Yamaguch-Shinozaki K. Molecular response of dehydration and low temperature difference and cross- talk between two stress signaling pathways. Curr Opin Plant Biol. 2003;3:217-3223.

89. Silva TM, Miranda RRS, Ferraz VP, Pereira MT, de Seiqueira EP, Alcantara AFC. Changes in the essential oil composition of leaves of Echinodorus macrophyllus exposed to $\gamma$ - radiation. Brazilian J Pharmacognosy. 2013;23(4): 600-7. https://doi.org/10.1590/50102-695X2013005000049.

90. Singh B, Datta P. Effect of low dose of gamma irradiation on plant and grain nutrition on wheat. Radiat Phys Chem. 2010;79(8):815-25.

91. Sivanesan I, Son MS, Lee JP, Jeong BR. Effects of silicon on growth of Tagetes patula L. boy orange and yellow boy seedlings cultured in an environment-controlled chamber. Propag Ornam Plants. 2010;10:136-40.

92. Snedecor GW, Cochran WG (1982) Statistical methods, the lowa State University press. $7^{\text {th }} \mathrm{Ed}, 2^{\text {nd }}$ printing, Ames, USA.

93. Spreitzer RJ. Role of the small subunit in ribulose-1,5-bisphosphate carboxylase/oxygenase. Arch Biochem Biophys. 2003;414(2):141-9. https:// doi.org/10.1016/S0003-9861(03)00171-1.

94. Todd GW. Photosynthesis and respiration of vegetative and reproductive parts of wheat and barley plants in response to increasing temperature. Proc Oklahoma Acad Sci. 1982;62:57-62.

95. Tomas-Barberan FA, Espin JC. Phenolic compounds and related enzymes as determinants of quality in fruit and vegetables. J Sci Food Agric. 2001;81(9): 853-76. https://doi.org/10.1002/jsfa.885.

96. Trevisan S, Francioso O, Quaggiotti S, Nardi S. Humic substances biological activity at the plant-soil interface. Plant Signaling Beha. 2010;5(6):635-43. https://doi.org/10.4161/psb.5.6.11211.

97. Tsonev T, Veikova V, Georgieva K, Hyde PF, Jones HG. Low temperature enhances photosynthetic down- regulation in french bean (Phaseolus vulgaris L.). Plants Annals Bot. 2003;91:343-52.

98. Wang B, Wang J, Liang H, Yi J, Zhang J, Lin L, et al. Reduced chilling injury in mango fruit by 2,4-dichlorophenoxyacetic acid and the antioxidant response. Postharvest Biol Tec. 2007:48:172-81.

99. Wang W, Anderson BT, Phillips N, Kaufmann RK, Potter C, Myneni RB. Feedbacks of vegetation on summertime climate variability over the north American grass land. Part I: Stat Anal Earth Inter. 2006;10 (in press).

100. Whistler RL, Wolform ML, Bemiller JN, Shafizadeh F. Anthrone colorimetric method. In: Methods in carbohydrate chemistry, vol. 1 P384. New York: Acadimic press; 1962.

101. Zaka R, Vandecasteele CM, Misset MT. Effects of low chronic doses of ionizing radiation on antioxidant enzymes and $\mathrm{G}_{6} \mathrm{PDH}$ activities in Stipa capillata (Poaceae). J Exp Bot. 2002;53(376):1979-87. https://doi.org/10.1093/ jxb/erf041.

102. Zhang L, Gao M, Zhang L, Li B, Han M, Alva AK, et al. Role of exogenous glycine betaine and humic acid in mitigating drought stress-induced adverse effects in Malus robusta seedlings. Turk J Bot. 2013;37:920-9. https:// doi.org/10.3906/bot-1212-21.

103. Zhu J, Liang YC, Ding YF, Li ZJ. Effects of silicon photosynthesis and its related physiological parameters in two winter wheat cultivates under cold stress. Sci Agric Sinica. 2006;39:1780-8.

104. Zhu JK. Salt and drought stress signal transduction in plants. Annu Res Plant Biol. 2002;53:279-93.

105. Zhu ZJ, Wei GQ, Li J, Qian QQ, Yu JQ. Silicon alleviates salt stress and increases antioxidant enzymes activity in leaves of salt-stressed cucumber (Cucumis sativus L.). Plant Sci. 2004;167(3):527-33. https://doi.org/10.1016/j. plantsci.2004.04.020.

106. Zvaigzne G, Karklina D, Seglina D, Krasnova I. Antioxidant in various citrus fruits juices. Chemine Technologija. 2009;3:56-61.

\section{Publisher's Note}

Springer Nature remains neutral with regard to jurisdictional claims in published maps and institutional affiliations. 